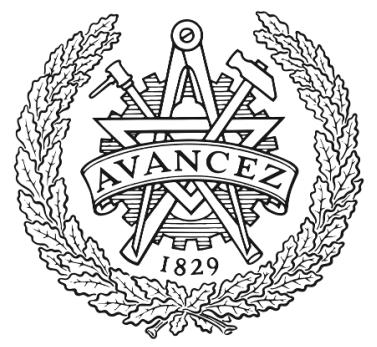

CHALMERS

UNIVERSITY OF TECHNOLOGY

\title{
Self-Standing, Robust Membranes Made of Cellulose Nanocrystals (CNCs) and a Protic Ionic Liquid: Toward Sustainable Electrolytes for Fuel Cells
}

Downloaded from: https://research.chalmers.se, 2023-04-26 10:41 UTC

Citation for the original published paper (version of record):

Danyliv, O., Strach, M., Nechyporchuk, O. et al (2021). Self-Standing, Robust Membranes Made of Cellulose Nanocrystals (CNCs) and a Protic Ionic

Liquid: Toward Sustainable Electrolytes for Fuel Cells. ACS Applied Energy Materials, 4(7):

6474-6485. http://dx.doi.org/10.1021/acsaem.1c00452

N.B. When citing this work, cite the original published paper. 


\title{
Self-Standing, Robust Membranes Made of Cellulose Nanocrystals (CNCs) and a Protic lonic Liquid: Toward Sustainable Electrolytes for Fuel Cells
}

\author{
Olesia Danyliv,* Michal Strach, Oleksandr Nechyporchuk, Tiina Nypelö, and Anna Martinelli*
}

Cite This: ACS Appl. Energy Mater. 2021, 4, 6474-6485

Read Online

ACCESS 1

山ll Metrics \& More

回国 Article Recommendations

SI Supporting Information

ABSTRACT: Energy-conversion devices based on the phenomenon of proton conduction, for example, polymer electrolyte membrane fuel cells (PEMFCs), require low cost and sustainable electrolytes with high ionic conductivity and good mechanical properties under anhydrous conditions and at temperatures up to $150{ }^{\circ} \mathrm{C}$. Biopolymers possess an intrinsic thermomechanical stability but an insufficient proton conductivity in the dry state, which however may be imparted by a protic ionic liquid (PIL). This work presents the preparation and properties of composite membranes made of cellulose nanocrystals (CNCs) and a PIL. The membranes are thermally stable and display an ionic conductivity within the range $10^{-4}-10^{-3} \mathrm{~S} / \mathrm{cm}$ for temperatures

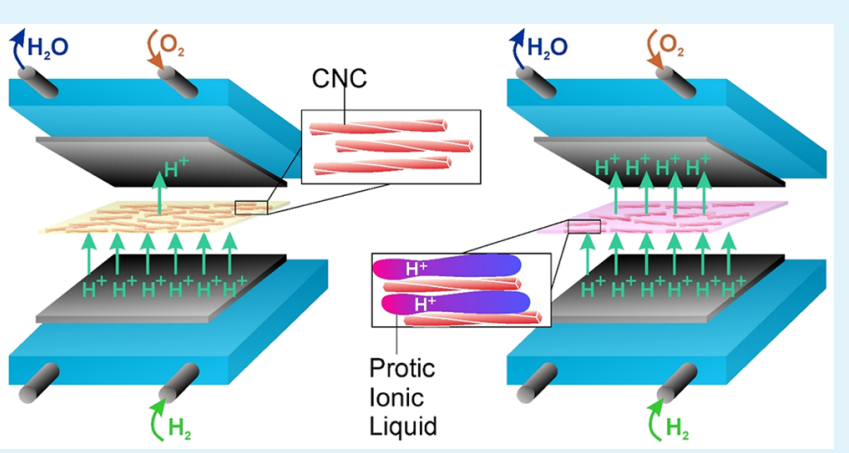
between 120 and $160{ }^{\circ} \mathrm{C}$. Moreover, the analysis of the biopolymer's apparent dimensions at nanoscale reveals a dependence of the CNCs' defects, twisting, and aggregation in the presence of the PIL. Preliminary tests using a simple fuel cell setup demonstrate a response of the membranes to the inlet of $\mathrm{H}_{2}$ gas, with a generation of electrical current. These findings provide a solid groundwork for further development and future studies of biopolymer/PIL electrolytes for energy applications.

KEYWORDS: cellulose nanocrystals, protic ionic liquid, polymer electrolyte, fuel cell, nanoscale

\section{INTRODUCTION}

There is a current emerging interest in the development of biopolymers as sustainable alternatives to synthetic polymer electrolytes for use in energy-conversion devices, such as the polymer electrolyte membrane fuel cell (PEMFC). ${ }^{1,2}$ The PEMFC is expected to become the main technology to power vehicles, especially heavy-duty and long-range ones, with the accompanying challenge of lowering the price and ensuring a longer lifetime than other sustainable technologies. ${ }^{3}$ This can only be achieved if the operational temperature of the PEMFC is increased to well above $90{ }^{\circ} \mathrm{C}$ (with a target of $120^{\circ} \mathrm{C}$ set by, for instance, the US Department of Energy for nextgeneration fuel cells, ${ }^{4}$ although higher temperature materials are also desired to fill the gap of available electrolytes in the temperature range $90-160^{\circ} \mathrm{C}$ ), which would raise the kinetics of redox reactions, enable the use of non-noble metals as catalysts, and result in a higher tolerance to fuel impurities. To operate at these temperatures, however, innovative electrolyte materials not dependent on water and performing under anhydrous conditions must be developed. Biopolymers, besides being sustainable by nature, possess a key advantage for use in PEMFCs, which is their high thermomechanical stability. For example, cellulose remains in its glassy state up to its degradation temperature which is around $200-220{ }^{\circ} \mathrm{C},{ }^{5}$ implying that the polymeric matrix will not be affected by the temperature window of operation envisaged for PEMFCs. This is different from the case of Nafion, the archetypical polymer electrolyte membrane (PEM) for PEMFCs, whose $T_{\mathrm{g}}$ is just below $100{ }^{\circ} \mathrm{C}$, making it suitable for operational temperatures only up to approximately $80-90{ }^{\circ} \mathrm{C}$. The available works on ion conducting biopolymers report ionic conductivities of about $10^{-3} \mathrm{~S} / \mathrm{cm}$ at $100-120{ }^{\circ} \mathrm{C}$ in the presence of water as the charge carrier ${ }^{6}$ and around $10^{-9} \mathrm{~S} / \mathrm{cm}$ in the dry state. ${ }^{7}$ To summarize, although dry biopolymers behave basically as insulators, their thermomechanical properties give promising expectations for the development of composites to be used as electrolytes in PEMFCs.

Protic ionic liquids (PILs), a subclass of ionic liquids bearing an exchangeable proton and having low volatility, may be used as an alternative to water as the charge carrier in a PEM. $^{8}$ In the context of biopolymers, however, ionic liquids have so far primarily been considered as solvents. In particular, aprotic

Received: February 11, 2021

Accepted: June 21, 2021

Published: July 6, 2021 
Scheme 1. Procedure Used to Obtain Self-Standing and Flexible CNC/Im/PIL Membranes

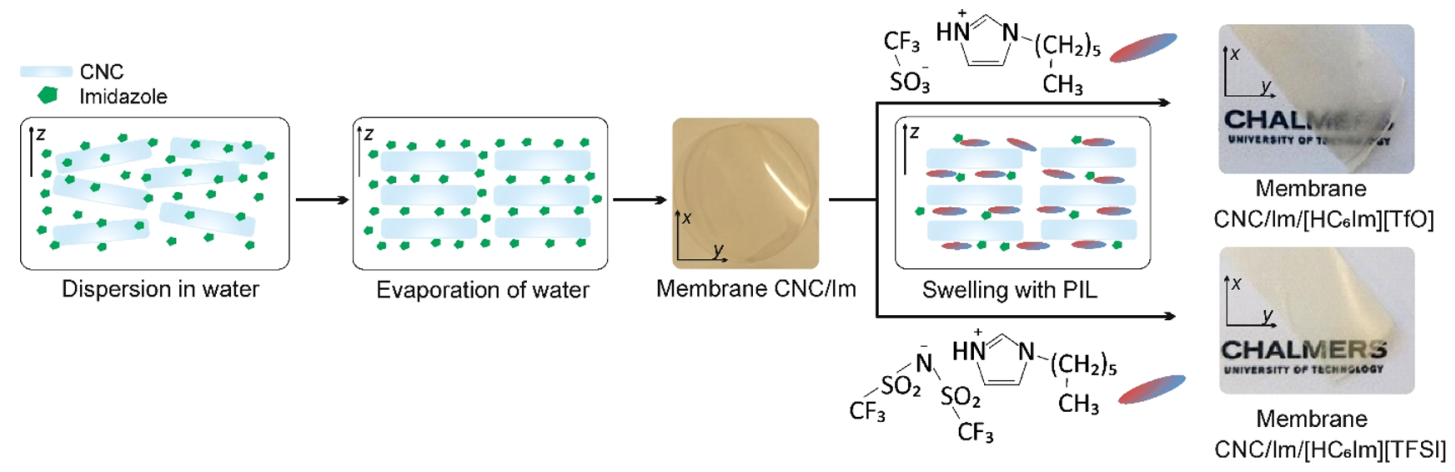

${ }^{a}$ University logo courtesy of Chalmers University of Technology

ionic liquids (APILs, ionic compounds not bearing an exchangeable proton), with for example 1-ethyl-3-methylimidazolium (EMIM), 1-butyl-3-methylimidazolium (BMIM), or 1-allyl-3-methylimidazolium (AMIM) as the cation and acetate $(\mathrm{Ac})$, chloride $(\mathrm{Cl})$, or bromide $(\mathrm{Br})$ as the anion, have widely been reported for dissolving cellulose. ${ }^{9-13}$ Some recent works have also described the preparation of biopolymer/APIL composites, sometimes also called ionogels, such as microcellulose/[EMIM]-methylphosphonate, ${ }^{14}$ cellulose nanocrystals/[AMIM] $[\mathrm{Cl}],{ }^{15}$ bacterial cellulose/[EMIM] $[\mathrm{TFSI}],{ }^{16}$ cotton/[BMIM] $[\mathrm{Cl}],{ }^{17}$ and chitosan or methylcellulose/ [BMIM][TFSI] composites. ${ }^{18}$ In two of them ${ }^{14,15}$ the ionic liquid was infiltrated into the biopolymer film followed by heating of the composite. These materials were aimed for electronic devices ${ }^{14}$ and optical applications as iridescent films. ${ }^{15}$ The other works describe the production of biopolymer/APIL composites by the casting/evaporation method. ${ }^{16-18}$ These considered mixing cellulose, bacterial cellulose, or chitosan with the APILs of choice diluted in water or alcohol as the volatile cosolvent, with subsequent evaporation of the cosolvent under mild conditions. However, the applicability of the casting/evaporation method depends very much on the compatibility between the ionic liquid, the biopolymer, and the solvent. In this context, Misenan et al. ${ }^{18}$ have realized materials for ion conduction and have reported polymer electrolytes with an ionic conductivity in the range of $4.0 \times 10^{-8}-1.5 \times 10^{-6} \mathrm{~S} / \mathrm{cm}$ at room temperature and up to $2.5 \times 10^{-6}-2.0 \times 10^{-5} \mathrm{~S} / \mathrm{cm}$ at $105{ }^{\circ} \mathrm{C}$.

We hypothesize that using a PIL instead of an APIL (as so far reported in the literature) together with a biopolymer will result in a polymer electrolyte of higher ionic conductivity than currently achievable due to the contribution from the mobile, exchangeable protons. Accordingly, this study describes the realization of PEM composed of cellulose nanocrystals (CNCs) and a PIL based on imidazolium, envisaged for energy applications. The choice of CNCs is inspired by their acidic functionalization and the promising conductivity data already reported by Bayer et al. ${ }^{6}$ for hydrated CNCs. According to another work, ${ }^{7}$ nanosized cellulose (crystalline (CNC) or fibrillated (CNF)) results in higher ionic conductivity compared to the microsized counterpart. Moreover, the results presented by Bayer et al. ${ }^{6}$ and Jankowska et al. ${ }^{7}$ show different conduction behavior for CNC and CNF, but the conditions of measurements were also different. In this work, we exclusively consider films based on CNCs. The choice of imidazolium-based protic ionic liquids relies on our previous studies ${ }^{19}$ and includes the immiscibility with water as an important aspect. In fact, although we aim for the anhydrous operation of the polymer electrolyte, water is the product of the oxygen reduction reaction at the cathode of a PEMFC, which brings along the risk of washing out the watermiscible components. Hence, with the aim to also address this issue, we have chosen hydrophobic imidazolium-based PILs with longer alkyl substituents on the cation, more precisely the ionic liquids $N$-hexylimidazolium trifluoromethylsulfonate $\left(\left[\mathrm{HC}_{6} \mathrm{Im}\right][\mathrm{TfO}]\right)$ and $N$-hexylimidazolium bis(trifluoromethylsulfonyl)imide $\left(\left[\mathrm{HC}_{6} \mathrm{Im}\right][\mathrm{TFSI}]\right)$.

In their pure state or in combination with a lithium salt, PILs have previously been combined with for example nanoporous matrices of silica ${ }^{20}$ and cross-linked polymer structures ${ }^{21}$ for applications in lithium-ion batteries. In fact, PILs encompass a class of compounds with a relatively high ionic conductivity and good thermal stability, which may be evolved to materials for use in several energy conversion and energy storage devices. Considering that the field of biopolymer/PIL composites is pretty much unexplored, the current work aims to give a detailed description of the correlation between the synthetic route used and the properties of the resulting materials. This information is important to continue the realization of high-performance ion-conducting materials based on sustainable precursors (i.e., a biopolymer and a nonvolatile organic electrolyte) and to increase the value of the PEMFC, whose positive impact on society and the environment is currently strongly emphasized.

\section{EXPERIMENTAL SECTION}

Preparation of Pristine Membranes Based on CNCs (CNCm). $1.0 \mathrm{~g}$ of CNCs (CelluForce NCC manufactured by CelluForce Inc., composed of cellulose sulfate sodium salt) was dispersed in $20 \mathrm{~g}$ of distilled water under magnetic stirring overnight. The suspension was degassed under reduced pressure, poured into a polyethylene Petri dish, and dried over two nights at ambient conditions. A self-standing $\mathrm{CNC}$ membrane (hereinafter named $\mathrm{CNCm}$ ) was formed, with an approximate thickness of $80 \mu \mathrm{m}$.

Preparation of CNC/PIL Composite Membranes. $1.50 \mathrm{~g}$ of $\mathrm{CNCs}$ and $0.46 \mathrm{~g}$ of imidazole (Merck) were dispersed in $40 \mathrm{~mL}$ of distilled water overnight under magnetic stirring. The dispersion was degassed under reduced pressure and cast onto a polyethylene Petri dish. Self-standing membranes, hereinafter called $\mathrm{CNC} / \mathrm{Im}$, with a thickness of 100-200 $\mu \mathrm{m}$, were formed after a day of water evaporation at ambient conditions. The protic ionic liquids $\mathrm{N}$ hexylimidazolium trifluoromethylsulfonate $\left(\left[\mathrm{HC}_{6} \mathrm{Im}\right][\mathrm{TfO}]\right.$, purchased from IoLiTec, 97\%) and $N$-hexylimidazolium bis(trifluoromethylsulfonyl)imide ([HC $\mathrm{Im}][\mathrm{TFSI}]$, purchased from IoLiTec, $>97 \%$ ) were first heated to $80{ }^{\circ} \mathrm{C}$. Then, preweighted pieces of the 
$\mathrm{CNC} / \mathrm{Im}$ membrane were immersed into the ionic liquid of choice. The ionic liquid uptake was monitored as a relative weight gain as a function of time. The swollen samples were labeled $\mathrm{CNC} / \mathrm{Im} /$ $\left[\mathrm{HC}_{6} \mathrm{Im}\right][\mathrm{TfO}](x)$ and $\mathrm{CNC} / \mathrm{Im} /\left[\mathrm{HC}_{6} \mathrm{Im}\right][\mathrm{TFSI}](x)$, where $x$ is the relative weight change of the membrane after swelling. The procedure used for preparing the described membrane electrolytes may be seen in Scheme 1.

Spectroscopic Analysis. Infrared spectra were acquired by using a PerkinElmer 2000 FT-IR spectrometer. The data were collected during 64 scans in the spectral range of $400-4000 \mathrm{~cm}^{-1}$ and in the attenuated total reflection (ATR) mode by using a diamond window. The spectral resolution was $2 \mathrm{~cm}^{-1}$. Raman spectra were recorded with an InVia Reflex spectrometer from Renishaw by using the 785 $\mathrm{nm}$ diode laser line (nominal power of $300 \mathrm{~mW}$ ) as the incident light. A grating of 1200 grooves $/ \mathrm{mm}$ and a $50 \times$ long working distance (LWD) objective from Leica were used. The acquisition of spectra was performed covering the spectral range $100-4000 \mathrm{~cm}^{-1}$ during 10 scans of $10 \mathrm{~s}$ each. In-depth Raman analysis was also performed covering the spectral range $200-1400 \mathrm{~cm}^{-1}$ during three scans of $3 \mathrm{~s}$ each with in-depth steps of $10 \mu \mathrm{m}$ across the whole thickness of the membranes. The calibration of the spectrometer was performed by referencing to the intensity of the first-order vibrational mode of silicon observed at $520.6 \mathrm{~cm}^{-1}$. Infrared and Raman spectra were further analyzed by using the software WIRE 5.0 and IGOR Pro 8.

Small-Angle X-ray Scattering (SAXS). SAXS measurements were performed by using a Mat:Nordic instrument from SAXSLAB/ Xenocs. The instrument was equipped with a microfocus $\mathrm{Cu} \mathrm{X}$-ray source and a Dectris Pilatus 300K R detector. The entire beam path was evacuated before each measurement to 0.2 mbar to minimize scattering from air. The sample-to-detector distance was calibrated by using silver behenate sandwiched between two mica windows kept in a sample holder for solid materials. The studied membranes were mounted in a similar way in the same type of sample holder. The SAXSGui software was used for processing the data, which was reduced by using standard protocols.

X-ray Diffraction (XRD). Two types of XRD instruments were used for this study. XRD patterns in transmission mode were acquired by using the same instrument as for the SAXS measurements by adjusting the distance between the sample and the detector. Apart from the Dectris Pilatus $300 \mathrm{~K} \mathrm{R}$ detector allowing the low angle detection $\left(2 \theta \leq 30^{\circ}\right)$, the detector Dectris $100 \mathrm{~K} \mathrm{R}$ was also used to study higher angles $\left(27^{\circ} \leq 2 \theta \leq 85^{\circ}\right)$. The sample preparation was identical with that used for the SAXS analysis.

In addition, XRD patterns in reflection geometry were acquired on a Bruker D8 Advance diffractometer with a $\mathrm{Cu}$ tube $\mathrm{X}$-ray source and a Lynxeye $\mathrm{Si}$ strip detector. The instrument was equipped with a Johansson $\mathrm{K} \alpha 1$ monochromator and operated in a $\theta / 2 \theta$ mode. In both cases, the instrumental broadening was determined by using a Corundum powder $\left(\alpha-\mathrm{Al}_{2} \mathrm{O}_{3}\right.$ NIST Standard 674$)$ measured in the same configuration as the sample and by using the same settings (i.e., same slit size, detector position, sample position, vacuum level, exposure time, and step size).

Thermal Analysis. The membranes were tested for thermal stability by thermogravimetric analysis (TGA) and for phase transitions by differential scanning calorimetry (DSC) using a TGA/DSC 3+ STARe instrument from Mettler Toledo. The following parameters were applied for the TGA measurements: heating from 40 to $320{ }^{\circ} \mathrm{C}$ at a rate of $5{ }^{\circ} \mathrm{C} / \mathrm{min}$, in an air flow of 50 $\mathrm{mL} / \mathrm{min}$. The membranes were tested as-prepared and after heat treatment at $150{ }^{\circ} \mathrm{C}$ (the temperature aimed for fuel cell applications) for $15 \mathrm{~h}$. For the DSC measurements the following conditions were applied: three cycles of heating and cooling from -20 to $150{ }^{\circ} \mathrm{C}$ and reverse, with a heating/cooling rate of $10^{\circ} \mathrm{C} / \mathrm{min}$ in a $\mathrm{N}_{2}$ flow of 50 $\mathrm{mL} / \mathrm{min}$.

Impedance Spectroscopy. A broadband dielectric spectrometer (BDS) from Novocontrol $\mathrm{GmbH}$ was used to measure the ionic conductivity. Samples with a diameter of $10 \mathrm{~mm}$ were placed between two gold-sputtered electrodes in a sealed cell. Measurements were performed by covering the frequency range $10^{-1}-10^{7} \mathrm{~Hz}$ as well as the temperature range $30-150{ }^{\circ} \mathrm{C}$ and using a stabilization time of 60 $s$ at each temperature.

Microscopy. Scanning electron microscopy (SEM) images were collected by using a Jeol JSM-7800F Prime instrument and applying an acceleration voltage of $5 \mathrm{kV}$. The samples were manually broken prior to measurement and sputtered with palladium; the broken edges were selected for SEM imaging.

Fuel Cell Test. Preliminary fuel cell tests were performed by using some of the components delivered with a rebuildable fuel cell kit (purchased from Fuel Cell Store). $\mathrm{H}_{2}$ gas diluted in argon (10\%) was used as the fuel fed at the anode side, and standard conditions were considered. In practice, a CNC/Im/PIL membrane was sandwiched between two commercial gas diffusion electrodes $\left(0.5 \mathrm{mg} / \mathrm{cm}^{2} \mathrm{Pt}\right.$ on a Vulcan-carbon cloth electrode) and held together by the gasketing and sealing system provided with the kit. Air was used as the oxidative gas, and the delivered current was measured by a simple multimeter.

\section{RESULTS AND DISCUSSION}

Fabrication of CNC/PIL Membrane Electrolytes. Currently known cellulose solvents are limited to $\mathrm{N}$-methylmorpholine $\mathrm{N}$-oxide (lyocell process), cuprammonium (process for making rayon), aqueous $\mathrm{NaOH}$ (after cellulose xanthation for viscose production and for the pristine cellulose), urea $/ \mathrm{NaOH}$ (process at low temperatures), dimethylacetamide/LiCl (limited to analytics due to low solubility), and some APILs (as mentioned in the Introduction). ${ }^{22,23} \mathrm{CNCs}$, on the contrary, disperse well in water, especially when their surface possesses acidic groups in the salt form, for example, sodium sulfate groups as in this work, which enable colloidal stability. As a consequence of this limited choice of practical and safe solubilizing/dispersing agents for $\mathrm{CNCs}$, it is inappropriate to fabricate CNC/PIL membranes with the most straightforward method of direct casting (i.e., solubilization of the biopolymer in the ionic liquid and the solvent, followed by pouring the solution on a plain surface and subsequent evaporation of the solvent, as also described in the Introduction). Neither is it expected that water (typically a good dispersant) in combination with a hydrophobic ionic liquid will result in satisfactory CNC/PIL membranes due to the inhomogeneous distribution of the mixing components. This is in fact what we did experience during the course of this work.

In a first approach, a film produced with direct casting of $0.50 \mathrm{~g}$ of CNC mixed with $0.25 \mathrm{~g}$ of $\left[\mathrm{HC}_{6} \mathrm{Im}\right][\mathrm{TfO}]$ in $15 \mathrm{~mL}$ of water indeed formed a self-standing but brittle membrane (i.e., $\left.\mathrm{CNC} /\left[\mathrm{HC}_{6} \mathrm{Im}\right][\mathrm{TfO}](67 / 33)\right)$. Although the membrane was less brittle than $\mathrm{CNCm}$, it appeared impossible to cut it into regular shapes as required for the impedance measurements. Moreover, including a higher concentration of $\left[\mathrm{HC}_{6} \mathrm{Im}\right][\mathrm{TfO}]$ in the composite membrane (mixing $0.25 \mathrm{~g}$ of $\mathrm{CNC}$ and $0.38 \mathrm{~g}$ of $\left[\mathrm{HC}_{6} \mathrm{Im}\right][\mathrm{TfO}]$ in $12 \mathrm{~mL}$ of water) and following the same procedure resulted in that self-standing membranes could not be obtained at all. We also made attempts to produce composites with the protic ionic liquid $\left[\mathrm{HC}_{6} \mathrm{Im}\right][\mathrm{TFSI}]$ (mixing $0.5 \mathrm{~g}$ of $\mathrm{CNC}$ with $0.13 \mathrm{~g}$ of $\left[\mathrm{HC}_{6} \mathrm{Im}\right][\mathrm{TFSI}]$ in $13 \mathrm{~mL}$ of distilled water), but despite the small quantity of the ionic liquid the $\mathrm{CNC} /\left[\mathrm{HC}_{6} \mathrm{Im}\right][\mathrm{TFSI}]-$ $(80 / 20)$ composition did not result in a self-standing membrane. This was concluded to be due to inadequate mixing of the components in the system, which was in fact evidenced when stirring of the suspension was stopped and a clear separation between the CNC dispersion in water and the hydrophobic $\left[\mathrm{HC}_{6} \mathrm{Im}\right][\mathrm{TFSI}]$ was observed. The success with the membrane formation of $\mathrm{CNC} /\left[\mathrm{HC}_{6} \mathrm{Im}\right][\mathrm{TfO}](67 / 33)$ can 
be explained by the more hydrophilic nature of $\left[\mathrm{HC}_{6} \mathrm{Im}\right]$ [TfO] compared to $\left[\mathrm{HC}_{6} \mathrm{Im}\right][\mathrm{TFSI}]$. However, given the brittleness of the $\mathrm{CNC} /\left[\mathrm{HC}_{6} \mathrm{Im}\right][\mathrm{TfO}](67 / 33)$ membrane, this method of preparation was not considered appropriate for our purposes.

In view of these results, the focus of the research shifted to another method to obtain CNC/PIL composite membranes, which is based on swelling a presynthesized biopolymer membrane in the PIL of choice. First, the pristine CNC membrane $(\mathrm{CNCm})$ was checked for swelling with the selected PILs, $\left[\mathrm{HC}_{6} \mathrm{Im}\right][\mathrm{TfO}]$, and $\left[\mathrm{HC}_{6} \mathrm{Im}\right][\mathrm{TFSI}]$. The maximum uptake of the PIL with any of these was limited to 2-3 wt \%, which may simply be ionic liquid residues on the surface of the films or residual water in the membranes exchanged for the PIL. Swelling with PILs of smaller molecular size, that is, $\left[\mathrm{HC}_{2} \mathrm{Im}\right][\mathrm{TfO}]$ and $\left[\mathrm{HC}_{2} \mathrm{Im}\right][\mathrm{TFSI}]$, at equivalent conditions resulted in a similar outcome. In addition to the fact that swelling of CNCm in the PILs does not occur, $\mathrm{CNCm}$ itself is a highly brittle material, and its handling will be an issue if larger scale production is considered. Supposedly, the penetration of large hydrophobic molecules is unfavorable due to strong intermolecular, intramolecular, ${ }^{24}$ and intercrystallite interactions dominating in the CNCm film. Moreover, in the dry film form, CNCs selfassemble into liquid crystal structures, ${ }^{25}$ which may be an additional reason for hindering bulky molecules from penetrating $\mathrm{CNCm}$. Hence, a partial breakup of the interactions in $\mathrm{CNCm}$ and the creation of a physical space between the nanocrystals (or the layers of nanocrystals) was hypothesized to be a viable approach.

To overcome the issue of a limited PIL uptake by the membrane, a relatively small, amphoteric, and water-soluble molecule able to contribute with hydrogen bonds, namely imidazole, was incorporated into the membrane of CNCs. Following the procedure described elsewhere ${ }^{26}$ albeit with a small modification, we mixed CNCs and imidazole in water overnight under magnetic stirring, casted the dispersion on a flat surface, and subsequently evaporated the water at ambient conditions. The resulting self-standing $\mathrm{CNC} / \mathrm{Im}$ membrane appeared transparent and was significantly less brittle than $\mathrm{CNCm}$. In the same line of thought, and for comparison, another weak base, that is, $N$-ethylimidazole, was also tested. The CNC/N-ethylimidazole combination did result in a selfstanding membrane but appeared more brittle than $\mathrm{CNC} / \mathrm{Im}$. The CNC/Im membrane could be cut into regularly shaped pieces, which is an important advantage when handling the membranes during and after immersion in the PIL. Considering the relatively high melting point of $\left[\mathrm{HC}_{6} \mathrm{Im}\right]$ [TfO] $\left(45^{\circ} \mathrm{C}\right.$, Figure S1), swelling of $\mathrm{CNC} / \mathrm{Im}$ with this PIL could not be performed at room temperature. Although the kinetics of swelling increases with heating, temperatures higher than $80{ }^{\circ} \mathrm{C}$ were intentionally avoided due to the presence of imidazole (see the Thermal Properties section). The maximum weight gain, after swelling overnight at $80^{\circ} \mathrm{C}$, was measured to be around $80 \mathrm{wt} \%$ for $\left[\mathrm{HC}_{6} \mathrm{Im}\right][\mathrm{TfO}]$ (sample labeled CNC/ $\left.\mathrm{Im} /\left[\mathrm{HC}_{6} \mathrm{Im}\right][\mathrm{TfO}](80)\right)$ and approximately $30 \mathrm{wt} \%$ for

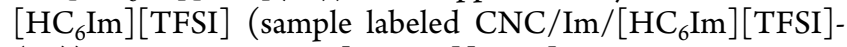
(30)). The CNC/Im/[ $\left.\mathrm{HC}_{6} \mathrm{Im}\right][\mathrm{TFSI}]$ composite appears translucent (Figure 1c), while $\mathrm{CNC} / \mathrm{Im} /\left[\mathrm{HC}_{6} \mathrm{Im}\right][\mathrm{TfO}]$ is more opaque (Figure 1a), likely due to the crystallization of the PIL phase, which was confirmed by XRD and DSC analyses (Figure S2). Both composites, however, are soft and (a)

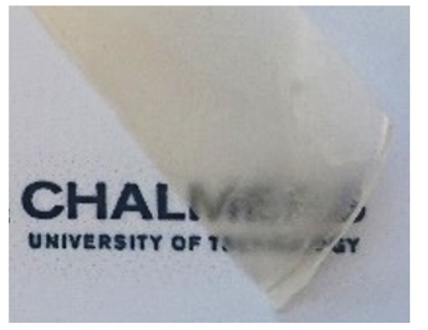

(b)

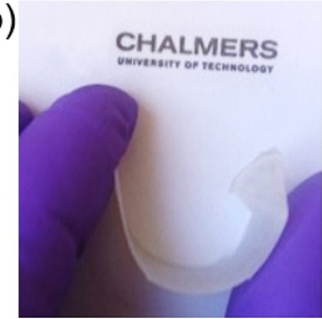

(c)

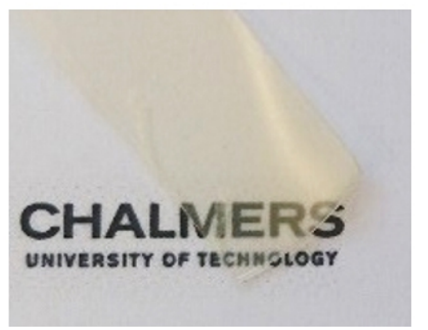

(d)

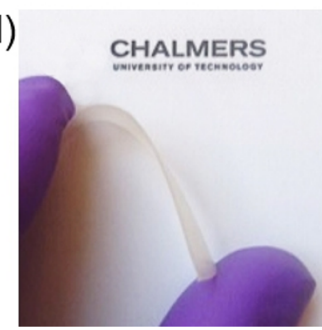

Figure 1. Images of selected membranes, i.e., $\mathrm{CNC} / \mathrm{Im} /\left[\mathrm{HC}_{6} \mathrm{Im}\right]$ $[\mathrm{TfO}](80)(\mathrm{a}, \mathrm{b})$ and $\mathrm{CNC} / \mathrm{Im} /\left[\mathrm{HC}_{6} \mathrm{Im}\right][\mathrm{TFSI}](30)(\mathrm{c}, \mathrm{d})$. Images of bent membranes $(\mathrm{b}, \mathrm{d})$ demonstrate that they are considerably less brittle than the pristine $\mathrm{CNCm}$. University logo courtesy of Chalmers University of Technology.

possess mechanical stability, as evidenced by the ability to bend the membranes without rupture (Figures $1 \mathrm{~b}$ and $1 \mathrm{~d}$ ).

Chemical Composition. Vibrational spectroscopy has been used to investigate in detail the chemical composition of the prepared membranes (Figure 2). The comparison of infrared spectra recorded for $\mathrm{CNCm}$ (a pristine $\mathrm{CNC}$ membrane) and CNC/Im (a membrane fabricated from the mixture of CNC and imidazole) with the reference spectra of imidazole and imidazolium suggests that imidazole in CNC/ $\mathrm{Im}$ is present exclusively as a neutral molecule (Figure 2a). This conclusion was drawn from observing the characteristic vibrations of neutral imidazole in the spectrum of $\mathrm{CNC} / \mathrm{Im}$. These can be seen at 915 and $931 \mathrm{~cm}^{-1}$ (out-of-plane bending of $\mathrm{CH}$ and $\mathrm{NH}$ and in-plane scissoring of the ring) and at 1487 and $1534 \mathrm{~cm}^{-1}$ (ring stretching and bending and $\mathrm{NH}$ bending), ${ }^{27,28}$ in addition to all the modes assigned to cellulose which match with those observed in the spectrum of $\mathrm{CNCm}$. Moreover, the typical features of imidazolium, that is, the narrow peak at $1590 \mathrm{~cm}^{-1}$ and the broad one at $1730 \mathrm{~cm}^{-1}, 28$ are absent in the infrared spectrum of $\mathrm{CNC} / \mathrm{Im}$. The position and assignment of the vibrational modes discussed above are summarized in Table 1. Notably, the infrared spectrum of $\mathrm{CNCm}$ is consistent with the spectra of cellulose available in the literature; ${ }^{29}$ see Table S1 for further details and a complete peak assignment.

These results are in accordance with the chemistry of $\mathrm{CNCm}$ and the presence of $-\mathrm{SO}_{3}{ }^{-} \mathrm{Na}^{+}$groups on the surface of the nanocrystals that cannot provide exchangeable $\mathrm{H}$ atoms for the protonation of imidazole. Similarly, the $-\mathrm{OH}$ groups of cellulose are too weakly acidic to protonate imidazole. This last point is in contrast to the results described in the previous work, ${ }^{30}$ which indicate the presence of protonated imidazole, that is, of imidazolium, in CMF/Im composites. Thus, to validate our results concerning the state of imidazole, we have recorded complementary Raman spectra (Figure 2b). The Raman-active modes of neutral imidazole are even more distinct, in particular the two intense modes at 1265 and 1326 $\mathrm{cm}^{-1}$ assigned to the $\mathrm{C}-\mathrm{H}$ out-of-plane bending and ring stretching modes in imidazole, ${ }^{31-34}$ while the typical feature of 

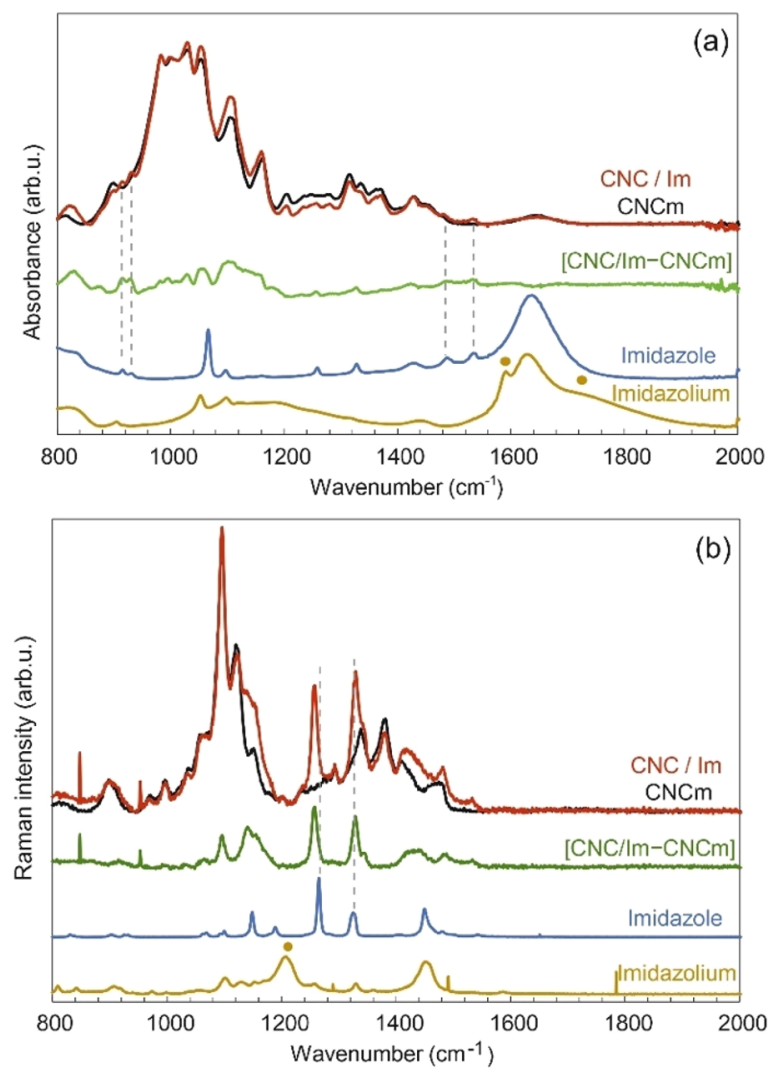

Figure 2. Infrared (a) and Raman (b) spectra of $\mathrm{CNCm}, \mathrm{CNC} / \mathrm{Im}$, imidazole (dissolved in water for infrared, in solid form for Raman), imidazolium (imidazole in acidic water), and the difference spectrum $[\mathrm{CNC} / \mathrm{Im}-\mathrm{CNCm}]$. The vertical dashed lines indicate the most intense vibrational modes in $\mathrm{CNC} / \mathrm{Im}$ assigned to imidazole. The dots indicate characteristic modes of imidazolium.

Table 1. Selection of Vibrational Modes Distinguishing Neutral from Protonated Imidazole ${ }^{a}$

\begin{tabular}{|c|c|c|c|}
\hline Compound & $\begin{array}{c}\text { Infrared } \\
\left(\mathrm{cm}^{-1}\right)\end{array}$ & $\begin{array}{l}\text { Raman } \\
\left(\mathrm{cm}^{-1}\right)\end{array}$ & Assignment \\
\hline \multirow[t]{6}{*}{ Imidazole } & $915 \mathrm{w}$ & $902 \mathrm{w}$ & $\gamma(\mathrm{CH})^{27,31}$ \\
\hline & $931 \mathrm{w}$ & $929 \mathrm{w}$ & $\gamma(\mathrm{NH}), \delta(\text { ring })^{27,31}$ \\
\hline & $1257 \mathrm{w}$ & 1265 vs & $\gamma(\mathrm{CH})_{\delta(\mathrm{CH})^{27}}{ }^{27}$ ring deformation, ${ }^{28}$ \\
\hline & $1329 \mathrm{w}$ & $1326 \mathrm{~s}$ & $\nu(\text { ring })^{27,28,31}$ \\
\hline & $1487 \mathrm{w}$ & $1481 \mathrm{w}$ & $\nu($ ring $),{ }^{27,28,31} \delta(\mathrm{NH})^{28}$ \\
\hline & $1534 \mathrm{w}$ & $1543 \mathrm{w}$ & $\nu($ ring $),{ }^{27,31} \delta(\text { ring })^{28}$ \\
\hline \multirow[t]{3}{*}{ Imidazolium } & & 1207 vs & $\begin{array}{l}\delta(\mathrm{CH}),^{31} \operatorname{ImH}^{+}(\text {current research }), \\
\text { possibly } \nu\left(\mathrm{C}^{+} \mathrm{N}\right) \text { and } \omega\left(\mathrm{C}^{+} \mathrm{H}\right)^{32}\end{array}$ \\
\hline & $1590 \mathrm{~s}$ & & $\begin{array}{l}\nu(\text { ring }) \text { and } \mathrm{CH} \text { bending, } \mathrm{ImH}^{+28}, \\
\mathrm{ImH}^{+}(\text {current research })\end{array}$ \\
\hline & $\begin{array}{c}1730 \mathrm{~m} \\
\text { and } \\
\text { broad }\end{array}$ & & $\mathrm{ImH}^{+28}$ (and current research) \\
\hline
\end{tabular}

${ }^{a}$ Abbreviations used: $\nu=$ stretching, $\delta=$ in-plane scissoring or bending, $\omega=$ out-of-plane bending or wagging, and $\gamma=$ out-of-plane vibrations. Peak intensities: vs $=$ very strong, $\mathrm{s}=$ strong, $\mathrm{m}=$ medium, and $\mathrm{w}=$ weak.

imidazolium at $1207 \mathrm{~cm}^{-1}\left(\mathrm{C}^{+} \mathrm{N}\right.$ stretching and $\mathrm{C}^{+} \mathrm{H}$ wagging $)^{31-34}$ is not observed in the spectrum of $\mathrm{CNC} / \mathrm{Im}$ (see also Table 1). The Raman spectrum of $\mathrm{CNCm}$ is consistent with the literature, while the assignment of modes is according to that proposed by Schenzel and Fischer ${ }^{35}$ (see Table S1). In both Figures $2 a$ and $2 b$, the difference of spectra
$[\mathrm{CNC} / \mathrm{Im}-\mathrm{CNCm}]$ leads to the conclusion that imidazole is present in its neutral (not protonated) form in the composite film.

Because Raman spectroscopy turned out to be more sensitive to the chemical composition, we have also used it for the compositional analysis of the biopolymer/PIL membranes, that is, the composites $\mathrm{CNC} / \mathrm{Im} /\left[\mathrm{HC}_{6} \mathrm{Im}\right][\mathrm{TfO}]$ and $\mathrm{CNC} / \mathrm{Im} /\left[\mathrm{HC}_{6} \mathrm{Im}\right][\mathrm{TFSI}]$ (Figures S3). In the spectra recorded after swelling, for the $\mathrm{CNC} / \mathrm{Im} / \mathrm{PIL}$ composites, the signatures of imidazole at 1265 and $1326 \mathrm{~cm}^{-1}$ are barely distinguishable. By analyzing a set of reference spectra, we conclude that this is related to both a partial exchange of imidazole during the swelling of the CNC/Im membrane with the PIL and an intimate interaction between imidazole and the PIL itself. More precisely, in the spectral range where the vibrations of the hexylimidazolium cation and of imidazole appear, between 1200 and $1600 \mathrm{~cm}^{-1}$, the spectrum of CNC/ $\mathrm{Im} /\left[\mathrm{HC}_{6} \mathrm{Im}\right][\mathrm{TfO}](38)$ is very similar to the spectrum of a mixture of $\left[\mathrm{HC}_{6} \mathrm{Im}\right][\mathrm{TfO}]$ and imidazole (mixed at a $0.9 / 0.1$ molar ratio). In other words, the low intensity of the signatures at 1265 and $1326 \mathrm{~cm}^{-1}$ (see also dashed vertical lines in Figure S3a) simply reflects the low imidazole content but not its absolute absence. It should be noted here that part of the imidazole is in fact washed out from the CNC/Im membrane during swelling, as demonstrated by Raman spectra collected from the liquid phase after the swelling procedure (not shown here). Moreover, the characteristic modes of the $[\mathrm{TfO}]^{-}$anion observed at $757 \mathrm{~cm}^{-1}\left(\delta_{\mathrm{s}} \mathrm{CF}_{3}\right)$ and $1037 \mathrm{~cm}^{-1}\left(\nu_{\mathrm{s}} \mathrm{SO}_{3}\right)$ in the pure $\left[\mathrm{HC}_{6} \mathrm{Im}\right][\mathrm{TfO}]$ shift to 759 and $1033 \mathrm{~cm}^{-1}$ in both the $\left[\mathrm{HC}_{6} \mathrm{Im}\right][\mathrm{TfO}] / \mathrm{Im}$ mixture and the $\mathrm{CNC} / \mathrm{Im} /\left[\mathrm{HC}_{6} \mathrm{Im}\right]$ [TfO](38) composite and appear broader. Simultaneously, a signature of the ring vibration observed at $1452 \mathrm{~cm}^{-1}$ broadens in the spectra of both $\left[\mathrm{HC}_{6} \mathrm{Im}\right][\mathrm{TfO}] / \mathrm{Im}$ and $\mathrm{CNC} / \mathrm{Im} /$ $\left[\mathrm{HC}_{6} \mathrm{Im}\right][\mathrm{TfO}](38)$. These observations indicate that the PIL and imidazole are well mixed and are at molecular proximity within the film and establish hydrogen bonds. ${ }^{36-39}$ The weak signatures of imidazole in the Raman spectra of $\left[\mathrm{HC}_{6} \mathrm{Im}\right]$ $[\mathrm{TFSI}] / \mathrm{Im}$ and $\mathrm{CNC} / \mathrm{Im} /\left[\mathrm{HC}_{6} \mathrm{Im}\right][\mathrm{TFSI}](29)$ (Figure S3b) are explained similarly to the case of the composites with $\left[\mathrm{HC}_{6} \mathrm{Im}\right][\mathrm{TfO}]$. However, the lesser effects on the modes at $742 \mathrm{~cm}^{-1}\left(\delta_{\mathrm{s}} \mathrm{CF}_{3}\right)$ and $1243 \mathrm{~cm}^{-1}\left(\nu_{\mathrm{s}} \mathrm{CF}_{3}\right)$ characteristic for the [TFSI] anion indicate a weaker interaction between imidazole and [TFSI $]^{-}$, which is consistent with previous findings in our group that imidazole added to an $\left[\mathrm{HC}_{n} \mathrm{Im}\right]$ [TFSI] ionic liquid preferably interacts with the alkylimidazolium cation. ${ }^{37}$ The only distinguishable change is a slight asymmetric broadening (toward higher wavenumbers) of the peak at $742 \mathrm{~cm}^{-1}$ in $\mathrm{CNC} / \mathrm{Im} /\left[\mathrm{HC}_{6} \mathrm{Im}\right][\mathrm{TFSI}]$ compared to the pure PIL or its mixture with imidazole. This may arise from confinement and/or interactions established between the PIL and CNCs. Nevertheless, it is not straightforward to make conclusions, from the spectral changes recorded by Raman or infrared spectroscopy, on the nature of interactions established between CNCs and imidazole.

Effect of Composition and Thickness on the Uptake of PILs. As an additional aspect, we have investigated the influence of the CNC:Im ratio and the CNC/Im thickness on the ability of the membrane to uptake the PIL. Three membranes, CNC/Im-1, CNC/Im-2, and CNC/Im-3, with an increasing amount of imidazole were prepared (see Table S2). These membranes were cast to obtain thin (around $200 \mu \mathrm{m}$ in cross section) and thick (400-800 $\mu \mathrm{m}$ in cross section) membranes. In-depth Raman analysis was performed to 
estimate the spatial distribution of imidazole through the thickness of $\mathrm{CNC} / \mathrm{Im}$. However, for the thicker membranes high quality spectra could not be collected from the whole thickness (due to lost spatial resolution); therefore, only results from the thinner ones are presented and discussed in Figure 3.

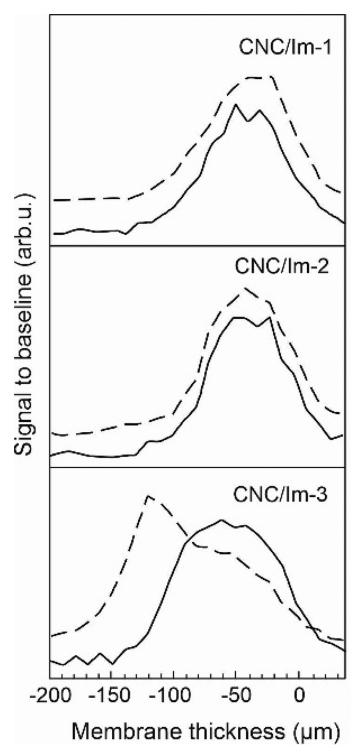

Figure 3. Distribution of imidazole within thin $\mathrm{CNC} / \mathrm{Im}$ membranes of different composition. The solid lines represent the integrated area under the feature at $270-550 \mathrm{~cm}^{-1}$ where the biopolymer contributes, while the dashed lines represent the integrated area under the feature at $1215-1285 \mathrm{~cm}^{-1}$ arising from imidazole.

Intensity versus position plots were created by using the integrated area under selected peaks arising from the polymer $\left(270-550 \mathrm{~cm}^{-1}\right)$ and imidazole $\left(1215-1285 \mathrm{~cm}^{-1}\right)$ exclusively (see also Figure $2 \mathrm{~b}$ ). Figure 3 shows that imidazole distributes homogeneously through the thickness of the membrane, except for the case of $\mathrm{CNC} / \mathrm{Im}-3$ whose distribution profile suggests the presence of excess imidazole accumulated at the bottom surface of the membrane in contact with the Petri dish. Moreover, Raman spectra revealed that in
CNC/Im-3 imidazole existed both as physically bound to CNC (as is the case for CNC/Im-1 and CNC/Im-2) and as bulk imidazole, with its characteristic peaks at 1148, 1188, 1262 , and $1448 \mathrm{~cm}^{-1}$ (see Figure S4 for more details). Figure 4 shows the swelling behavior of the $\mathrm{CNC} / \mathrm{Im}-1, \mathrm{CNC} / \mathrm{Im}-2$ and $\mathrm{CNC} / \mathrm{Im}-3$ membranes, both thin (Figure $4 \mathrm{a}$ ) and thick (Figure $4 \mathrm{~b}$ ), with the ionic liquids $\left[\mathrm{HC}_{6} \mathrm{Im}\right][\mathrm{TfO}]$ (violet symbols) and $\left[\mathrm{HC}_{6} \mathrm{Im}\right][\mathrm{TFSI}]$ (orange symbols). A first qualitative result is that the rate of swelling for the thinner membranes is considerably higher than that of the thicker ones (to note that all the membranes were swollen equally long). The faster PIL uptake by the thinner membranes is a benefit that adds to the already known lower ohmic resistivity; this confirms the advantage of fabricating membranes as thin as possible provided that the mechanical properties are not affected. Moreover, the amount of imidazole present in the membranes does not influence the ionic liquid uptake significantly. Based on these results, the thin $\mathrm{CNC} / \mathrm{Im}-2$ membrane was selected for further investigations.

Thermal Properties of CNC/Im/PILs Composite Membranes. Ion-conducting materials intended to be used at anhydrous conditions in next-generation PEMFCs are required to be mechanically and chemically stable up to at least $150{ }^{\circ} \mathrm{C}$. A straightforward method to verify chemical stability over temperature is TGA, while DSC is a valuable complementary technique to study phase transitions that do not necessarily involve mass changes. Typically, no phase transitions are detected by DSC for cellulose or cellulose derived materials, which was also the case for the membranes $\mathrm{CNCm}, \mathrm{CNC} / \mathrm{Im}$, and $\mathrm{CNC} / \mathrm{Im} /\left[\mathrm{HC}_{6} \mathrm{Im}\right][\mathrm{TFSI}]$ considered in this work. Only the membrane $\mathrm{CNC} / \mathrm{Im} /\left[\mathrm{HC}_{6} \mathrm{Im}\right][\mathrm{TfO}]$ revealed a melting/ crystallization peak related to the protic ionic liquid $\left[\mathrm{HC}_{6} \mathrm{Im}\right]$ [TfO] (Figure S5). The presence of this transition indicates that the $\left[\mathrm{HC}_{6} \mathrm{Im}\right][\mathrm{TfO}]$ domains are large enough for the ionic liquid molecules to organize in the crystalline phase.

Figure 5a shows that $\mathrm{CNCm}$ is stable up to $230{ }^{\circ} \mathrm{C}$, with a slightly smaller weight loss between 80 and $230{ }^{\circ} \mathrm{C}$ for the heat-treated membrane, most likely due to the lower content of physically bound water after the heat treatment. A similar behavior was observed for the $\mathrm{CNC} / \mathrm{Im}$ membrane (Figure
Thinner membranes

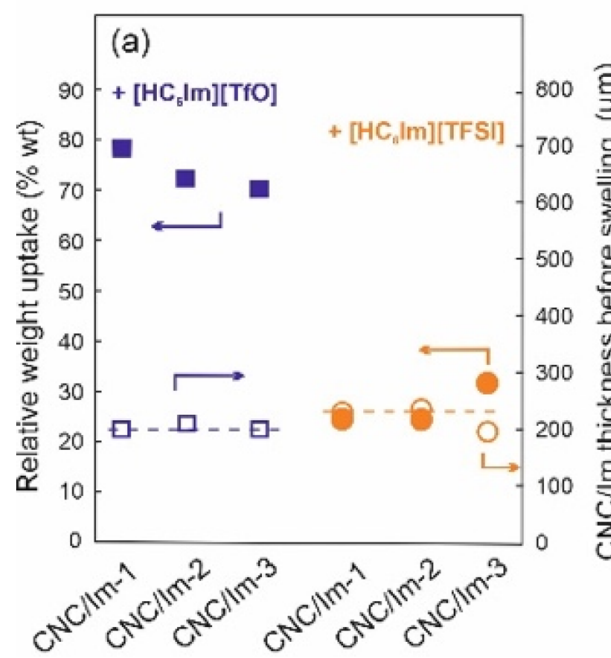

Thicker membranes

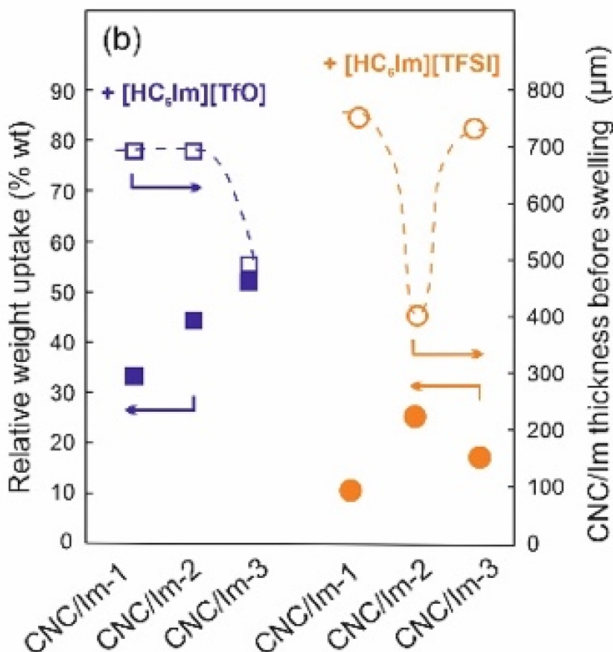

Figure 4. Swelling behavior of $\mathrm{CNC} / \mathrm{Im}$ membranes with $\left[\mathrm{HC}_{6} \mathrm{Im}\right][\mathrm{TfO}]$ and $\left[\mathrm{HC}_{6} \mathrm{Im}\right][\mathrm{TFSI}]$ as a function of composition and thickness: for thinner membranes, $\sim 200 \mu \mathrm{m}$ (a), and for thicker membranes, $\sim 400-800 \mu \mathrm{m}$ (b). 


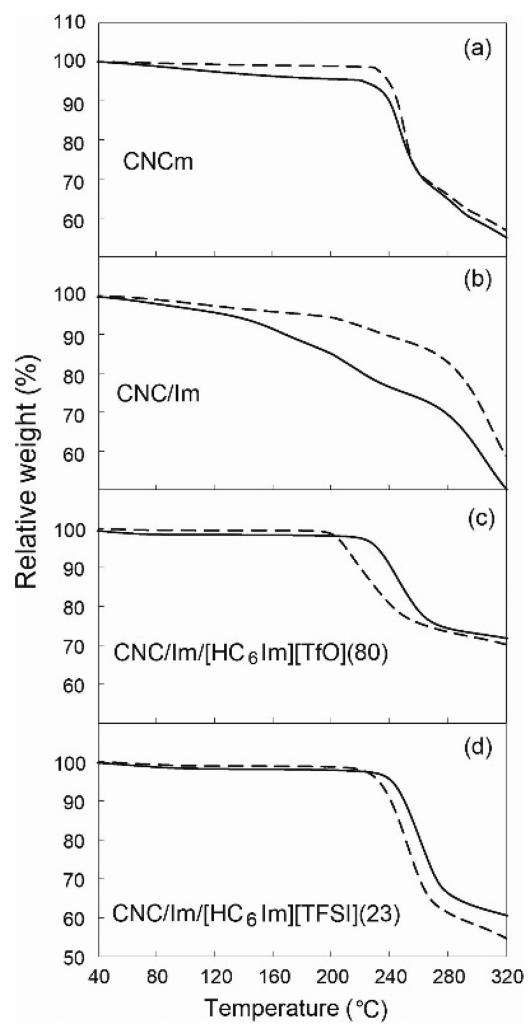

Figure 5. TGA curves of as-prepared (solid lines) and heat-treated (dashed lines) samples: $\mathrm{CNCm}$ (a), $\mathrm{CNC} / \mathrm{Im}$ (b), CNC/Im/ $\left[\mathrm{HC}_{6} \mathrm{Im}\right][\mathrm{TfO}](80)(\mathrm{c})$, and $\mathrm{CNC} / \mathrm{Im} /\left[\mathrm{HC}_{6} \mathrm{Im}\right][\mathrm{TFSI}](23)(\mathrm{d})$.

$5 \mathrm{~b})$, but in this case the difference in mass loss profiles between as-prepared and heat-treated samples was so substantial that it may not be related to water evaporation only. The as-prepared $\mathrm{CNC} / \mathrm{Im}$ membrane lost ca. $25 \%$ of its weight up to $230{ }^{\circ} \mathrm{C}$, which correlates well with the mass of imidazole intentionally added (precisely 23\%) into the membrane. Therefore, the slope of the TGA curve reflects the continuous desorption of physically and weakly bound imidazole molecules. This explanation is in disagreement with a previous thermal study of a CNC:Im blend, ${ }^{40}$ for which the loss of imidazole was observed to start at $150{ }^{\circ} \mathrm{C}$, claiming the material as a promising high-temperature proton conductor. In our opinion, the $\mathrm{CNC} / \mathrm{Im}$ composite has poor thermal stability, since the observed decomposition results from the correlated loss of water and imidazole that are known to establish mutual interactions. ${ }^{41}$ Hence, we judge that $\mathrm{CNC} / \mathrm{Im}$ is per se not an interesting electrolyte material, although, as we show in this work, it plays an important role as an intermediate material for the subsequent uptake of the ionic liquid. The $\mathrm{CNC} / \mathrm{Im} / \mathrm{PIL}$ composites show a very good thermal stability as well, with a minor difference between the as-prepared and the heat-treated samples (Figures $5 \mathrm{c}$ and $5 \mathrm{~d}$ ). CNC/Im/ $\left[\mathrm{HC}_{6} \mathrm{Im}\right][\mathrm{TfO}](80)$ displays a mass loss of only $23 \mathrm{wt} \%$ that starts at $230{ }^{\circ} \mathrm{C}$ for the as-prepared and at $200{ }^{\circ} \mathrm{C}$ for the heattreated membranes (note that the content of PIL is above 44 wt \%). The $\mathrm{CNC} / \mathrm{Im} /\left[\mathrm{HC}_{6} \mathrm{Im}\right][\mathrm{TFSI}](23)$ composite shows a relatively higher mass loss, of $35 \%$ in the temperature range 230-280 ${ }^{\circ} \mathrm{C}$, which could indicate a worse affinity for the biopolymeric matrix. Overall, the TGA data evidence that the presence of the $\mathrm{PIL} /$ imidazole mixture in the composite membrane does not have a negative impact on the thermal stability of the biopolymer. This gives the cellulose-based membranes a significant potential for use at high operational temperatures of up to at least $180{ }^{\circ} \mathrm{C}$, which is beyond the target for next-generation fuel cells (i.e., $\mathrm{T}>120^{\circ} \mathrm{C}$ ).

Conductivity of CNC/Im/PILs Composite Membranes. The ionic conductivity of all CNC-based membranes was measured by broadband dielectric spectroscopy in the temperature window $30-150{ }^{\circ} \mathrm{C}$, a range selected from the TGA results to ensure chemical stability of the composites with the PILs. Despite the poorer thermal stability of CNC/Im in the above-mentioned temperature range, it was still measured as a reference. This sample showed an ionic conductivity between $3.3 \times 10^{-7}$ and $4.5 \times 10^{-5} \mathrm{~S} / \mathrm{cm}$ (Figure $6 \mathrm{a})$, which is lower than the values previously reported for a
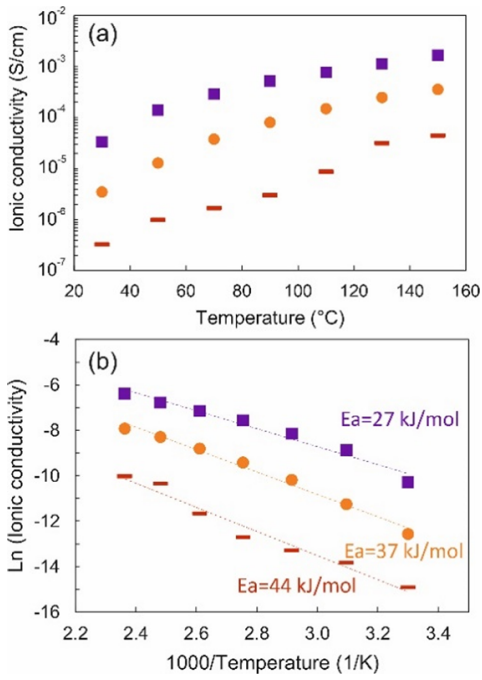

Figure 6. Ionic conductivity as a function of temperature for the membranes CNC/Im (-), CNC/Im/[HC $\left./ \mathrm{H}_{6} \mathrm{Im}\right][\mathrm{TfO}](80)(\boldsymbol{\square})$, and $\mathrm{CNC} / \mathrm{Im} /\left[\mathrm{HC}_{6} \mathrm{Im}\right][\mathrm{TFSI}](23)(\mathbf{0})$ in a linear plot (a) and in an Arrhenius plot (b).

material of similar composition. ${ }^{26}$ The ionic conductivity of $\mathrm{CNCm}$ is not shown in the figure because the values are in the range $10^{-14}-10^{-11} \mathrm{~S} / \mathrm{cm}$. (These values are much lower than previously reported, ${ }^{7}$ most likely because the CNC sample in the reported study is in the acidic state while the CNC membrane in this work is sodium-neutralized one.)

The CNC/Im/PIL composites showed an ionic conductivity of almost 2 orders of magnitude higher than their precursor $\mathrm{CNC} / \mathrm{Im}$, with values in the range $4 \times 10^{-6}-2 \times 10^{-3} \mathrm{~S} / \mathrm{cm}$ between 30 and $150{ }^{\circ} \mathrm{C}$. In addition, the membrane containing $\left[\mathrm{HC}_{6} \mathrm{Im}\right][\mathrm{TfO}]$, which is also the composite with the higher ionic liquid content, displays a higher ionic conductivity. Most importantly, the values found for these composites are comparable to those measured for other more established polymer/protic ionic liquid electrolyte concepts. ${ }^{19,42,43}$ However, the CNC-based electrolytes presented here provide a higher thermal stability than those based on Nafion or other perfluorinated polymers that, apart from dehydration, also suffer from mechanical weakening at temperatures above their $T_{\mathrm{g}}$ (e.g., the $T_{\mathrm{g}}$ of Nafion is $\sim 90{ }^{\circ} \mathrm{C}$ ). From an Arrhenius plot of the measured conductivity values (Figure $6 \mathrm{~b}$ ), we could estimate the activation energy $E_{\mathrm{a}}$, which decreases from $44 \mathrm{~kJ} /$ mol $(0.45 \mathrm{eV})$ for the precursor CNC/Im to only $27 \mathrm{~kJ} / \mathrm{mol}$ $(0.28 \mathrm{eV})$ for the $\mathrm{CNC} / \mathrm{Im} /\left[\mathrm{HC}_{6} \mathrm{Im}\right][\mathrm{TfO}](80)$ composite. Unfortunately, the ${ }^{1} \mathrm{H}$ NMR spectra of the CNC/Im/PIL composite membranes do not provide a resolution high 
enough to perform diffusion experiments and hence study the contribution from exchangeable mobile protons. Nevertheless, our previous works have already shown that the copresence of imidazole and imidazolium cations promotes the self-diffusion of protons, ${ }^{37,37}$ which is a desired phenomenon for fuel cell applications.

Nanoscale Structure in CNC/Im/PILs Membranes. The small-angle scattering pattern of CNCs of different charge density and ionic strength has mainly been described for the case of suspensions in water. ${ }^{44-50}$ The advantage of studying diluted suspensions is probing the form factor of the scattering objects, with no interference from the structure factor. ${ }^{48-50}$ The latter has significant contribution when the scattering objects get proximate and organize in more complex structures, which is in fact the case for dry films of CNCs. Penttilä et al. $^{51,52}$ have recently reported a small-angle X-ray and neutron scattering study of dry wood samples (containing a mixture of cellulose, hemicellulose, and lignin) and fitted the data to the model of hexagonally packed cylinders. In addition, Liu et al. $^{45,46}$ have made an extensive SAXS study of $\mathrm{CNC} /$ water droplets during dehydration, including the fascinating case of levitating droplets. This study provides useful insights into the scattering profile of dry $\mathrm{CNC}$, that is, the material after complete dehydration. The X-ray data collected for the CNC membranes prepared in this work are analyzed in light of the knowledge gained from these relevant previous studies of dry wood, ${ }^{51,52}$ dry CNC, ${ }^{4,46}$ and other cellulosic samples in water suspension. ${ }^{4-50,53}$

Figure 7a presents the SAXS patterns of the $\mathrm{CNCm}, \mathrm{CNC} /$ $\mathrm{Im}$, and various $\mathrm{CNC} / \mathrm{Im} / \mathrm{PIL}$ composites. The scattering intensity of $\mathrm{CNCm}$ in the low- $Q$ range $\left(0.006-0.04 \AA^{-1}\right)$ shows a linear dependence with a slope of -2 . This can result from a lamellar type structure, with the CNCs organizing in discrete parallel planes. This structure is consistent with the collected SEM images (Figures S6a and S6c), showing layers of $\mathrm{CNCs}$ that build up the membrane's thickness. The correlation peak observed for $\mathrm{CNCm}$ in the high- $Q$ region (0.04-0.23 $\AA^{-1}$ ) was further analyzed by using the $f(Q)=Q^{2} \cdot I(Q)$ representation, which results in a more distinct feature (Figure $7 \mathrm{~b})$. Considering that dry $\mathrm{CNCm}$ consists exclusively of proximate nanocrystals, the scattering feature appearing at 0.13 $\AA^{-1}$ and associated with a separation distance, $d$, of $5 \mathrm{~nm}(d=$ $2 \pi / q)$ is assigned to the center-to-center distance between CNC crystals. This dimension is in good agreement with that reported for a dehydrated levitating droplet of suspended CNCs. $^{46}$ In addition, this dimension was confirmed by the analysis of peak widths in the collected XRD patterns (see Figure 8 and data in Table 2).

The crystallite dimensions reported in Table 2 were determined from the XRD patterns via the Scherrer equation (taking into account the instrumental broadening) by applying a fitting procedure that considers both amorphous and background contributions. An automatic fitting based on least-squares minimization was also performed, and the results are presented in Table S3. The (110), (110), and (200) reflections were used to determine the cross section of the nanocrystals, corresponding to facets $a$ and $b$ and to the diagonal $d$ of the cross section, respectively. ${ }^{54-56}$ From the (004) reflection the mean size of a single crystalline domain along the crystal length was derived. ${ }^{5,57}$ The instrumental resolution was not high enough to distinguish between the (110) and (110) reflections; hence, the size determination in these directions suffers from an error of $\sim 1.5 \mathrm{~nm}$. Under these
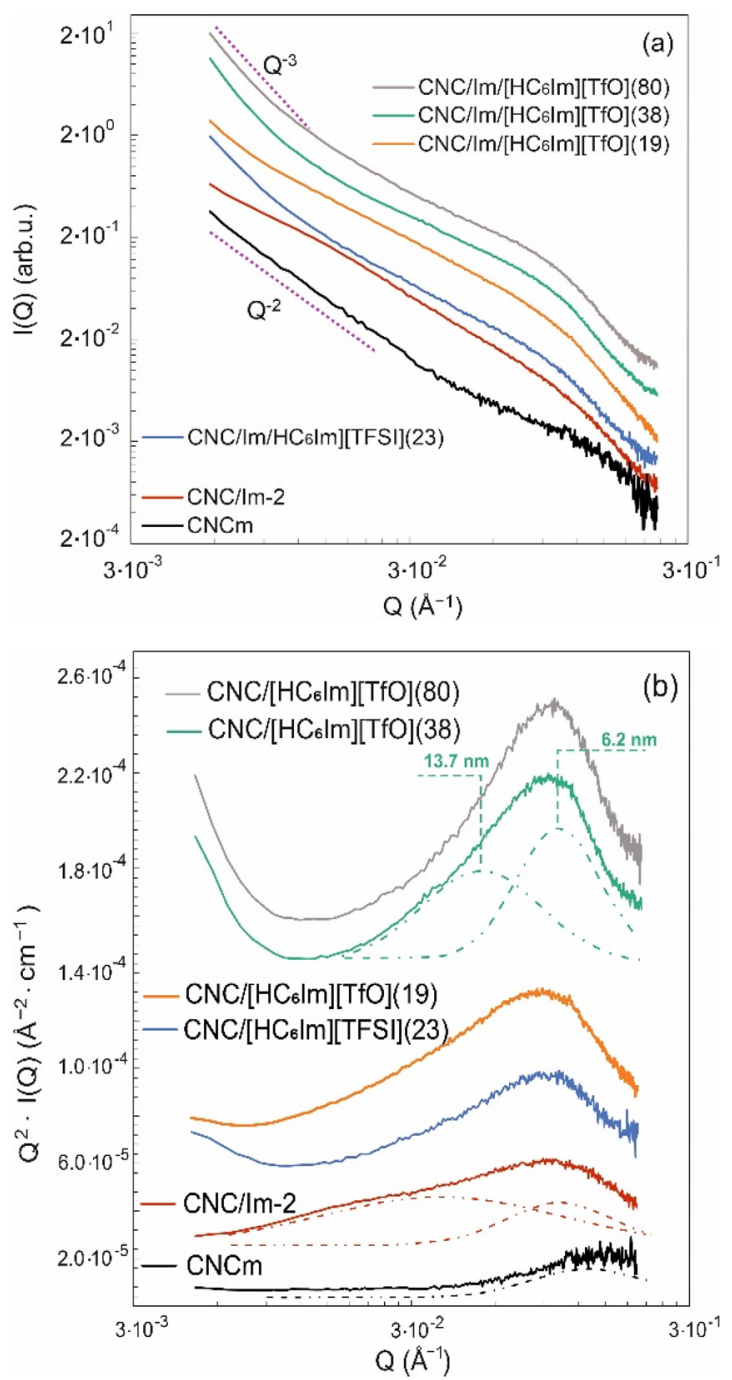

Figure 7. SAXS profiles of $\mathrm{CNCm}, \mathrm{CNC} / \mathrm{Im}-2, \mathrm{CNC} / \mathrm{Im} /\left[\mathrm{HC}_{6} \mathrm{Im}\right]-$ [TFSI $](23)$, and $\mathrm{CNC} / \mathrm{Im} /\left[\mathrm{HC}_{6} \mathrm{Im}\right][\mathrm{TfO}]$ for different PIL content in (a) the $f(Q)=I(Q)$ representation and (b) the $f(Q)=Q^{2} \cdot I(Q)$ representation (a Kratky plot).

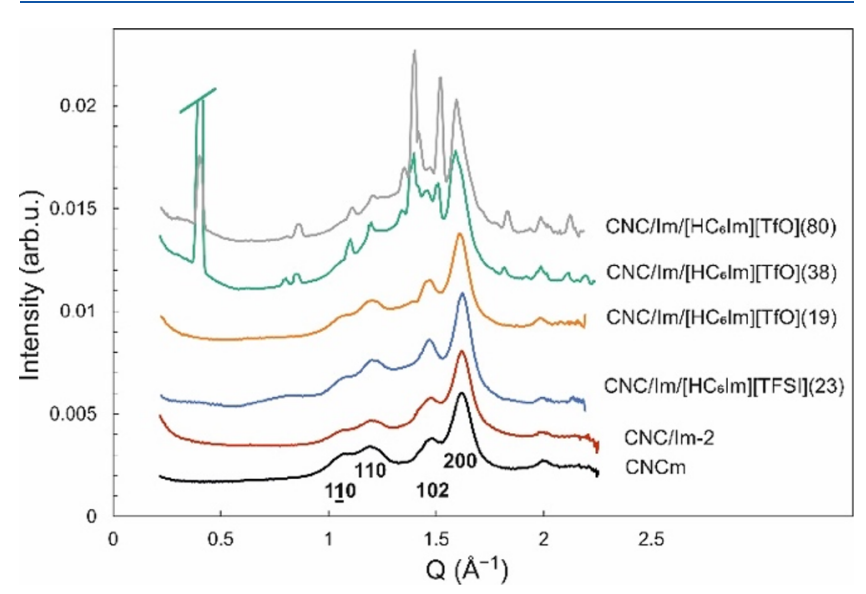

Figure 8. $\mathrm{XRD}$ profiles of $\mathrm{CNCm}, \mathrm{CNC} / \mathrm{Im}-2, \mathrm{CNC} / \mathrm{Im} /\left[\mathrm{HC}_{6} \mathrm{Im}\right]$ [TFSI $](23)$, and $\mathrm{CNC} / \mathrm{Im} /\left[\mathrm{HC}_{6} \mathrm{Im}\right][\mathrm{TfO}]$ for different PIL contents.

circumstances, the crystallite cross section in $\mathrm{CNCm}$ was calculated to be $6-7 \mathrm{~nm}$, which agrees well with the results 
Table 2. Size of Scattering Features Obtained from the Analysis of SAXS and XRD Data

\begin{tabular}{|c|c|c|c|c|c|c|}
\hline \multirow[b]{3}{*}{ Sample } & \multirow{3}{*}{$\begin{array}{l}\text { SAXS size of } \\
\text { scattering } \\
\text { features } \\
( \pm 0.5 \mathrm{~nm})\end{array}$} & & \multicolumn{4}{|c|}{ XRD size of crystallites } \\
\hline & & & \multicolumn{3}{|c|}{$\begin{array}{c}\text { Cross-sectional }( \pm 1.5 \\
\mathrm{nm})\end{array}$} & \multirow{2}{*}{$\begin{array}{c}\begin{array}{c}\text { Longitudinal } \\
( \pm 10 \mathrm{~nm})\end{array} \\
l(004)\end{array}$} \\
\hline & & & $\begin{array}{c}a \\
(1 \underline{1} 0)\end{array}$ & $\begin{array}{c}b \\
(110)\end{array}$ & $\begin{array}{c}d \\
(200)\end{array}$ & \\
\hline $\mathrm{CNCm}$ & 5 & & 6 & 8 & 7 & 45 \\
\hline $\mathrm{CNC} / \mathrm{Im}-2$ & 6 & 17 & 6 & 6 & 8 & 45 \\
\hline $\begin{array}{l}\mathrm{CNC} / \mathrm{Im} / \\
{\left[\mathrm{HC}_{6} \mathrm{Im}\right]} \\
{\left[\mathrm{TfO}^{-}\right]}\end{array}$ & 6 & 13 & 6 & 7 & 9 & 90 \\
\hline $\begin{array}{c}\mathrm{CNC} / \mathrm{Im} / \\
{\left[\mathrm{HC}_{6} \mathrm{Im}\right]} \\
{[\mathrm{TFSI}]}\end{array}$ & 6 & 13 & 7 & 6 & 9 & 90 \\
\hline
\end{tabular}

from SAXS. The single crystalline domain along the crystal in $\mathrm{CNCm}$ was determined to be $45 \mathrm{~nm}$. This value is considerably smaller than the reported length of commercial wood-based CNCs, which is $160 \mathrm{~nm}$ on average. ${ }^{58}$ An explanation for this deviation may be the nonperiodicity of the crystalline lattice. ${ }^{59,60}$

The SAXS profile of the CNC/Im membrane reveals a less distinct slope than $\mathrm{CNCm}$ (Figure $7 \mathrm{a}$ ) due to two proximate and broad features centered at $\sim 0.103$ and $\sim 0.038 \AA^{-1}$, which are better visualized in the representation used in Figure $7 \mathrm{~b}$. These correspond to scattering objects of 6 and $17 \mathrm{~nm}$ in size. The increase of the intercrystalline distance from 5 to $6 \mathrm{~nm}$ can be rationalized by the presence of imidazole well dispersed over the surface of the nanocrystals. Although this small dimensional difference lies on the verge of the instrumental resolution, a qualitative evidence that the nanocrystals in $\mathrm{CNC} / \mathrm{Im}$ are larger and more separated than for the case of $\mathrm{CNCm}$ is found in the SEM images given in Figures S6b and S6d. The correlation distance of $17 \mathrm{~nm}$ may result from the aggregation of several nanocrystals, apparently three nanocrystals here, which can be induced by attractive forces such as hydrogen bonds or Coulombic interactions. This is for instance the case discussed for CNCs with sulfuric acid groups anchored to their surface (i.e., $\mathrm{CNC}-\mathrm{SO}_{3} \mathrm{H}$ ), which have displayed an aggregation number of eight in diluted suspensions. ${ }^{47}$ On this line, it is plausible that imidazole added in-between CNCs introduces similar attractive forces. Finally, the dimensional parameters determined from the XRD pattern of $\mathrm{CNC} / \mathrm{Im}$ did not show substantial differences with respect to those of $\mathrm{CNCm}$.

The composite membranes CNC/Im/PIL also show two correlation distances in SAXS. The one of $6 \mathrm{~nm}$ is independent of the content and type of the PIL and, along with the results from XRD, indicates that the cross-sectional dimension of the crystallites does not change substantially upon swelling. Nevertheless, the value derived from the (200) reflection increases to $9 \mathrm{~nm}$, suggesting some degree of interaction between the PIL and the CNCs. The second repeating distance of about $13 \mathrm{~nm}$ observed by SAXS points to an aggregation number reduced to only two nanocrystals, which stays the same for the two PILs investigated. A remarkable observation is the apparent length of a crystalline region, which increases from $45 \mathrm{~nm}$ in CNCm and CNC/Im to $90 \mathrm{~nm}$ in the $\mathrm{CNC} / \mathrm{Im} / \mathrm{PIL}$ membranes. The considerable deviations in the analysis of the (004) reflection may originate from alteration in twisting of the CNCs. ${ }^{61}$ The increase in the single crystallite domain length in the $\mathrm{CNC} / \mathrm{Im} / \mathrm{PIL}$ membranes may indicate the partial untwisting of the CNCs when interacting with the PILs. So far, it is not possible to estimate the influence of this intrinsic change on the properties of the $\mathrm{CNC} / \mathrm{Im} / \mathrm{PIL}$ materials, especially on ion conduction. Nevertheless, the observation of such physical change at the nanoscale points on a synergy between the biopolymer and the PIL.

Fuel Cell Demonstration. To verify whether this type of membranes has any real potential, we have performed some preliminary fuel cell tests. For this purpose, we have selected the $\mathrm{CNC} / \mathrm{Im} /\left[\mathrm{HC}_{6} \mathrm{Im}\right][\mathrm{TfO}]$ composition, based on the higher liquid uptake and hence the higher conductivity in comparison to the $\left[\mathrm{HC}_{6} \mathrm{Im}\right][\mathrm{TFSI}]$ analogous (see Figure 6). A new, larger $\mathrm{CNC} / \mathrm{Im}$ membrane was prepared and after the ionic liquid uptake a square piece of $5 \times 5 \mathrm{~cm}^{2}$ was cut. For testing, we created an own assembly consisting of the CNC/ $\mathrm{Im} /\left[\mathrm{HC}_{6} \mathrm{Im}\right][\mathrm{TfO}]$ membrane $(\sim 100 \mu \mathrm{m}$ thick $)$ pressed between two commercial gas diffusion electrodes and held together by the gasketing and sealing system provided in a rebuildable fuel cell kit (Figure 9a). The cell was operated in

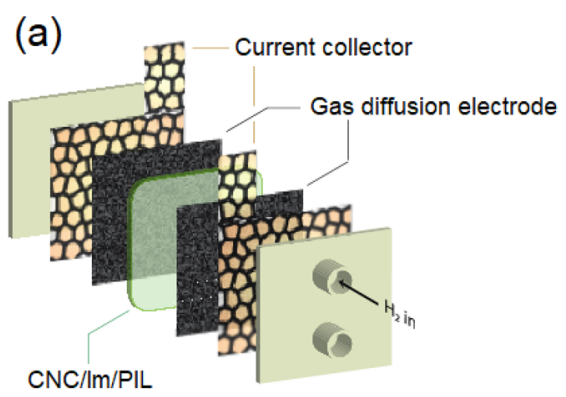

(b)

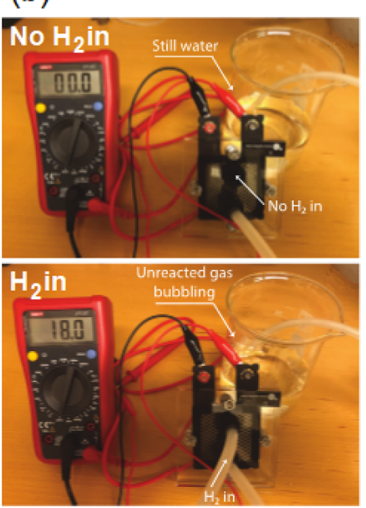

(c)

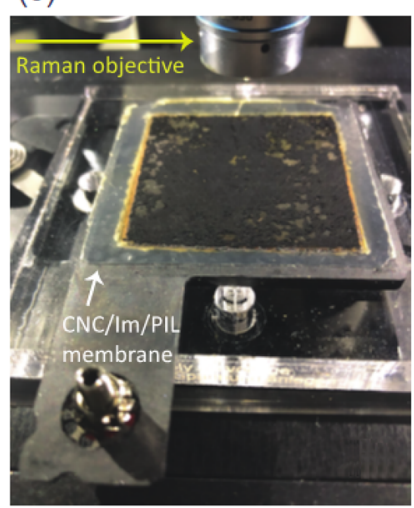

Figure 9. (a) Illustration of the fuel cell assembly used for the test and based on a CNC/Im/PIL membrane as the proton exchange membrane. (b) Fuel cell setup before (upper image) and after (lower image) the inlet of the $\mathrm{H}_{2}$ gas at the anode. (c) Half-cell after disassembly and after the fuel cell tests (the white arrow points to the contour of the $\mathrm{CNC} / \mathrm{Im} / \mathrm{PIL}$ membrane).

the $\mathrm{H}_{2}$ /air mode feeding the anode with $10 \% \mathrm{H}_{2}$ in argon. This system responded readily to the inlet of $\mathrm{H}_{2}$, delivering currents in the range 10-18 mA (see Movie $\mathrm{S} 1$ and Figure 9b). Although the current was measured to be stable over time (with no issues of water management at the cathode side), we recognize that this is a modest performance. In fact, a MEA based on an ionic liquid is expected to perform well at high temperatures, while the test was done at room temperature. As a note, at room temperature the $\mathrm{CNC} / \mathrm{Im} / \mathrm{PIL}$ membrane displays an ionic conductivity 100 times lower than hydrated 
Nafion, while this would be reversed above $90{ }^{\circ} \mathrm{C}$ (in the case of no additional humidification). Also, the used gasketing and sealing system was not optimized to the thickness of our membrane. This can affect negatively the catalyst/membrane contact implying that part of the inlet gas may flow back unreacted with the result of lower currents than potentially expected. On the positive side, we observed that after disassembly of the MEA the membrane had remained intact (see Figure 9c). Moreover, the chemical composition of the membrane was verified by Raman spectroscopy (not shown here) to be the same before and after the fuel cell tests. To summarize, the transport of protons through the $\mathrm{CNC} / \mathrm{Im} /$ PIL membrane is conceptually demonstrated by the delivery of some current that, however, is low due to the nonoptimal operational conditions used. The next coming studies must therefore be focused on better controlled fuel cell tests by using more advanced devices that allow keeping the MEA at temperatures above $90{ }^{\circ} \mathrm{C}$ and, possibly, by using appropriate gas diffusion electrodes developed to be compatible with cellulose.

\section{CONCLUSIONS}

We demonstrate that it is possible to fabricate solid state electrolytes based on a biopolymer, that is, CNCs, and an ionic liquid bearing exchangeable protons, that is, a protic ionic liquid. The shortcomings of several procedures are presented, and it is shown that to enable an efficient incorporation of the protic ionic liquid and to achieve self-standing, nonbrittle membranes, the fabrication process must occur via an intermediate $\mathrm{CNC} /$ imidazole casted film. In this precursor, the amphoteric molecules of imidazole occupy the space between crystallites, which facilitates swelling and hence the preparation of $\mathrm{CNC} / \mathrm{Im} / \mathrm{PIL}$ composite membranes. These show a chemical stability up to at least $200{ }^{\circ} \mathrm{C}$ as well as a satisfying ionic conductivity, ranging between $10^{-4}$ and $10^{-3} \mathrm{~S} /$ $\mathrm{cm}$ in the temperature interval $90-160{ }^{\circ} \mathrm{C}$ under anhydrous conditions. Based on the conductivity values, these composite materials are competitive to membranes obtained from synthetic polymers. Moreover, the temperature window of performance of CNC/Im/PIL is even beyond the operational temperature targeted for future, nonhumidified, fuel cell devices. The copresence of imidazole and imidazolium (i.e., the cation of the PIL) and the low activation energy measured are aspects that allow classifying the presented materials as good proton conductors. The analysis of their structure at nanoscale revealed that the studied PILs tend to alter the crystallites, which may arise from a direct interaction between the imidazolium cations and the biopolymer. The preliminary fuel cell test that we have performed confirms the potential of these materials as proton exchange membranes, even though improvement is needed. To conclude, this study presents the first example (to our knowledge) of a CNC-based membrane combined with a protic ionic liquid displaying properties that give potential for use in electrochemical devices, in particular fuel cells operating at intermediate temperatures and dry conditions. The presented results will serve as a reference for further studies on materials with similar chemical compositions.

\section{ASSOCIATED CONTENT}

\section{(s) Supporting Information}

The Supporting Information is available free of charge at https://pubs.acs.org/doi/10.1021/acsaem.1c00452.
Figure S1: DSC profiles of $\left[\mathrm{HC}_{6} \mathrm{Im}\right][\mathrm{TfO}]$; Figure S2: $\mathrm{XRD}$ profiles of $\mathrm{CNCm},\left[\mathrm{HC}_{6} \mathrm{Im}\right][\mathrm{TfO}], \mathrm{CNC} / \mathrm{Im} /$ $\left[\mathrm{HC}_{6} \mathrm{Im}\right][\mathrm{TfO}]$, and DSC profiles of $\mathrm{CNC} / \mathrm{Im} /$ $\left[\mathrm{HC}_{6} \mathrm{Im}\right][\mathrm{TfO}]$; Table S1: complete set of observed vibrational spectra and their assignment; Figure S3: Raman spectra of the pure components and of the CNC/Im/PIL composites; Table S2: weight ratios of components used for the $\mathrm{CNC} / \mathrm{Im}$ preparation; Figure S4: Raman spectra of $\mathrm{CNC} / \mathrm{Im}$; Figure S5: DSC for $\mathrm{CNCm}, \mathrm{CNC} / \mathrm{Im}, \mathrm{CNC} / \mathrm{Im} /\left[\mathrm{HC}_{6} \mathrm{Im}\right][\mathrm{TFSI}](30)$, and $\mathrm{CNC} / \mathrm{Im} /\left[\mathrm{HC}_{6} \mathrm{Im}\right][\mathrm{TfO}](80)$; Table S3: summary on scattering features from the SAXS and XRD analyses; Figure S6: SEM images of CNCm, CNC/Im-2, CNC/ $\mathrm{Im} /\left[\mathrm{HC}_{6} \mathrm{Im}\right][\mathrm{TfO}](19)$, and $\mathrm{CNC} / \mathrm{Im} /\left[\mathrm{HC}_{6} \mathrm{Im}\right]$ [TFSI $]$ (23) (PDF)

Movie S1 (MP4)

\section{AUTHOR INFORMATION}

\section{Corresponding Authors}

Olesia Danyliv - Department of Chemistry and Chemical Engineering, Chalmers University of Technology, 41296 Gothenburg, Sweden; (1) orcid.org/0000-0002-7406-0255; Email: olesia.danyliv@ri.se

Anna Martinelli - Department of Chemistry and Chemical Engineering, Chalmers University of Technology, 41296 Gothenburg, Sweden; 10 orcid.org/0000-0001-9885-5901; Email: anna.martinelli@chalmers.se

\section{Authors}

Michal Strach - Chalmers Materials Analysis Laboratory, Department of Physics, Chalmers University of Technology, 41296 Gothenburg, Sweden

Oleksandr Nechyporchuk - RISE Research Institutes of Sweden, 43122 Mölndal, Sweden; (1) orcid.org/0000-00017178-5202

Tiina Nypelö - Department of Chemistry and Chemical Engineering, Chalmers University of Technology, 41296 Gothenburg, Sweden; Wallenberg Wood Science Center, Chalmers University of Technology, Gothenburg, Sweden; - orcid.org/0000-0003-0158-467X

Complete contact information is available at:

https://pubs.acs.org/10.1021/acsaem.1c00452

\section{Notes}

The authors declare no competing financial interest.

\section{ACKNOWLEDGMENTS}

The authors acknowledge the Swedish Foundation for Strategic Research (SSF, grant FFL-15 0092) and the Knut \& Alice Wallenberg Foundation (Wallenberg Academy Fellows, grant 2016-0220) for the financial support as well as Chalmers Materials Analysis Laboratory (CMAL) for the XRD and SAXS instruments. Mina Fazilati and Szilvia Vavra (PhD students at Chalmers) are acknowledged for their help in using optical microscopy and collecting SEM images, respectively. The authors thank Eduard Maurina Morais for help in mounting the cell for a fuel cell test.

\section{ABBREVIATIONS}

PEMFC, polymer electrolyte membrane fuel cell; PEM, polymer electrolyte membrane; PIL, protic ionic liquid; APIL, aprotic ionic liquid; CNC, cellulose nanocrystals; 
CNF, cellulose nanofibrils; TGA, thermogravimetric analysis; DSC, differential scanning calorimetry; XRD, X-ray diffraction; SAXS, small-angle X-ray scattering; SEM, scanning electron microscopy.

\section{REFERENCES}

(1) Muthumeenal, A.; Pethaiah, S. S.; Nagendran, A. Biopolymer composites in fuel cells. In Biopolymer Composites in Electronics; Elsevier: 2017; pp 185-217.

(2) Vilela, C.; Silvestre, A. J.; Figueiredo, F. M.; Freire, C. S. Nanocellulose-based materials as components of polymer electrolyte fuel cells. J. Mater. Chem. A 2019, 7 (35), 20045-20074.

(3) https://blog.ballard.com/fuel-cell-commercial-vehicles.

(4) DOE Technical Targets for Polymer Electrolyte Membrane Fuel Cell Components. https://www.energy.gov/eere/fuelcells/doetechnical-targets-polymer-electrolyte-membrane-fuel-cellcomponents.

(5) Kargin, V. A.; Kozlov, P. V.; Wang, N.-c. In Classification Temperature of Cellulose; Doklady Akademii Nauk, Russian Academy of Sciences: 1960; pp 356-358.

(6) Bayer, T.; Cunning, B. V.; Selyanchyn, R.; Nishihara, M.; Fujikawa, S.; Sasaki, K.; Lyth, S. M. High temperature proton conduction in nanocellulose membranes: paper fuel cells. Chem. Mater. 2016, 28 (13), 4805-4814.

(7) Jankowska, I.; Pankiewicz, R.; Pogorzelec-Glaser, K.; Ławniczak, P.; Łapiński, A.; Tritt-Goc, J. Comparison of structural, thermal and proton conductivity properties of micro-and nanocelluloses. Carbohydr. Polym. 2018, 200, 536-542.

(8) Sun, J.; Jordan, L. R.; Forsyth, M.; Macfarlane, D. R. AcidOrganic base swollen polymer membranes. Electrochim. Acta 2001, 46 (10-11), 1703-1708.

(9) Swatloski, R. P.; Spear, S. K.; Holbrey, J. D.; Rogers, R. D. Dissolution of cellose with ionic liquids. J. Am. Chem. Soc. 2002, 124 (18), 4974-4975.

(10) Zhang, H.; Wu, J.; Zhang, J.; He, J. 1-Allyl-3-methylimidazolium chloride room temperature ionic liquid: a new and powerful nonderivatizing solvent for cellulose. Macromolecules 2005, 38 (20), 8272-8277.

(11) Kosan, B.; Michels, C.; Meister, F. Dissolution and forming of cellulose with ionic liquids. Cellulose 2008, 15 (1), 59-66.

(12) Sashina, E.; Novoselov, N. Effect of structure of ionic liquids on their dissolving power toward natural polymers. Russ. J. Gen. Chem. 2009, 79 (6), 1057-1062.

(13) Mood, S. H.; Golfeshan, A. H.; Tabatabaei, M.; Abbasalizadeh, S.; Ardjmand, M. Comparison of different ionic liquids pretreatment for barley straw enzymatic saccharification. 3 Biotech 2013, 3 (5), 399-406.

(14) Thiemann, S.; Sachnov, S. J.; Pettersson, F.; Bollström, R.; Österbacka, R.; Wasserscheid, P.; Zaumseil, J. Cellulose-based ionogels for paper electronics. Adv. Funct. Mater. 2014, 24 (5), 625-634.

(15) Liu, P.; Guo, X.; Nan, F.; Duan, Y.; Zhang, J. Modifying mechanical, optical properties and thermal processability of iridescent cellulose nanocrystal films using ionic liquid. ACS Appl. Mater. Interfaces 2017, 9 (3), 3085-3092.

(16) Smith, C. J.; Wagle, D. V.; O’Neill, H. M.; Evans, B. R.; Baker, S. N.; Baker, G. A. Bacterial cellulose ionogels as chemosensory supports. ACS Appl. Mater. Interfaces 2017, 9 (43), 38042-38051.

(17) Haq, M. A.; Habu, Y.; Yamamoto, K.; Takada, A.; Kadokawa, J.i. Ionic liquid induces flexibility and thermoplasticity in cellulose film. Carbohydr. Polym. 2019, 223, 115058-115065.

(18) Misenan, M.; Isa, M.; Khiar, A. Electrical and structural studies of polymer electrolyte based on chitosan/methyl cellulose blend doped with BMIMTFSI. Mater. Res. Express 2018, 5 (5), 055304.

(19) Danyliv, O.; Martinelli, A. Nafion/Protic Ionic Liquid Blends: Nanoscale Organization and Transport Properties. J. Phys. Chem. C 2019, 123 (23), 14813-14824.
(20) Marie, A.; Said, B.; Galarneau, A.; Stettner, T.; Balducci, A.; Bayle, M.; Humbert, B.; Le Bideau, J. Silica based ionogels: interface effects with aprotic and protic ionic liquids with lithium. Phys. Chem. Chem. Phys. 2020, 22 (41), 24051-24058.

(21) Stettner, T.; Lingua, G.; Falco, M.; Balducci, A.; Gerbaldi, C. Protic Ionic Liquids-Based Crosslinked Polymer Electrolytes: A New Class of Solid Electrolytes for Energy Storage Devices. Energy Technol. 2020, 8 (11), 2000742.

(22) Liebert, T. Cellulose solvents-remarkable history, bright future. In Cellulose Solvents: For Analysis, Shaping and Chemical Modification; ACS Publications: 2010; pp 3-54.

(23) Klemm, D.; Philpp, B.; Heinze, T.; Heinze, U.; Wagenknecht, W. Comprehensive Cellulose Chemistry; Wiley-VCH Verlag GmbH: 1998; Vol. 1, pp 9-165.

(24) Dufresne, A. Nanocellulose: From Nature to High Performance Tailored Materials; Walter de Gruyter GmbH \& Co KG: 2017; pp 83-124.

(25) Hamad, W. On the development and applications of cellulosic nanofibrillar and nanocrystalline materials. Can. J. Chem. Eng. 2006, 84 (5), 513-519.

(26) Tritt-Goc, J.; Bielejewski, M.; Markiewicz, E.; Pankiewicz, R. Proton conductivity and proton dynamics in nanocrystalline cellulose functionalized with imidazole. Carbohydr. Polym. 2019, 225, 115196.

(27) Hodgson, J. B.; Percy, G. C.; Thornton, D. A. The infrared spectra of imidazole complexes of first transition series metal (ii) nitrates and perchlorates. J. Mol. Struct. 1980, 66, 81-92.

(28) Richmond, W. N.; Faguy, P. W.; Weibel, S. C. An in situ infrared spectroscopic study of imidazole films on copper electrodes. J. Electroanal. Chem. 1998, 448 (2), 237-244.

(29) Ilharco, L. M.; Garcia, A. R.; Lopes da Silva, J.; Vieira Ferreira, L. Infrared approach to the study of adsorption on cellulose: influence of cellulose crystallinity on the adsorption of benzophenone. Langmuir 1997, 13 (15), 4126-4132.

(30) Jankowska, I.; Ławniczak, P.; Pogorzelec-Glaser, K.; Łapiński, A.; Pankiewicz, R.; Tritt-Goc, J. Cellulose microfibers surface treated with imidazole as new proton conductors. Mater. Chem. Phys. 2020, 239, 122056

(31) Carter, D. A.; Pemberton, J. E. Surface-enhanced Raman scattering of the acid-base forms of imidazole on silver. Langmuir 1992, 8 (4), 1218-1225.

(32) Markham, L. M.; Mayne, L. C.; Hudson, B. S.; Zgierski, M. Z. Resonance Raman studies of imidazole, imidazolium, and their derivatives: the effect of deuterium substitution. J. Phys. Chem. 1993, 97 (40), 10319-10325.

(33) Garfinkel, D.; Edsall, J. T. Raman spectra of amino acids and related compounds. VIII. Raman and infrared spectra of imidazole, 4methylimidazole and histidine1-3. J. Am. Chem. Soc. 1958, 80 (15), 3807-3812.

(34) Majoube, M.; Henry, M.; Chinsky, L.; Turpin, P. Preresonance Raman spectra for imidazole and imidazolium ion: interpretation of the intensity enhancement from a precise assignment of normal modes. Chem. Phys. 1993, 169 (2), 231-241.

(35) Schenzel, K.; Fischer, S. NIR FT Raman spectroscopy-a rapid analytical tool for detecting the transformation of cellulose polymorphs. Cellulose 2001, 8 (1), 49-57.

(36) Yaghini, N.; Gómez-González, V.; Varela, L. M.; Martinelli, A. Structural origin of proton mobility in a protic ionic liquid/imidazole mixture: Insights from computational and experimental results. Phys. Chem. Chem. Phys. 2016, 18 (33), 23195-23206.

(37) Hasani, M.; Varela, L. M.; Martinelli, A. Short-Range Order and Transport Properties in Mixtures of the Protic Ionic Liquid [C2HIm][TFSI] with Water or Imidazole. J. Phys. Chem. B 2020, 124 (9), 1767-1777.

(38) Garaga, M. N.; Dracopoulos, V.; Werner-Zwanziger, U.; Zwanziger, J. W.; Maréchal, M.; Persson, M.; Nordstierna, L.; Martinelli, A. A long-chain protic ionic liquid inside silica nanopores: enhanced proton mobility due to efficient self-assembly and decoupled proton transport. Nanoscale 2018, 10 (26), 12337-12348. 
(39) Yaghini, N.; Abdurrokhman, I.; Hasani, M.; Martinelli, A. Transport properties and intermolecular interactions in binary mixtures based on the protic ionic liquid ethylimidazolium triflate and ethylene glycol. Phys. Chem. Chem. Phys. 2018, 20 (35), 2298022986.

(40) Tritt-Goc, J.; Jankowska, I.; Pogorzelec-Glaser, K.; Pankiewicz, R.; Ławniczak, P. Imidazole-doped nanocrystalline cellulose solid proton conductor: synthesis, thermal properties, and conductivity. Cellulose 2018, 25 (1), 281-291.

(41) Zhao, L.; Smolarkiewicz, I.; Limbach, H.-H.; Breitzke, H.; Pogorzelec-Glaser, K.; Pankiewicz, R.; Tritt-Goc, J.; Gutmann, T.; Buntkowsky, G. Imidazole-doped cellulose as membrane for fuel cells: structural and dynamic insights from solid-state NMR. J. Phys. Chem. C 2016, 120 (35), 19574-19585.

(42) Tigelaar, D. M.; Waldecker, J. R.; Peplowski, K. M.; Kinder, J. D. Study of the incorporation of protic ionic liquids into hydrophilic and hydrophobic rigid-rod elastomeric polymers. Polymer 2006, 47 (12), 4269-4275.

(43) Lee, S.-Y.; Yasuda, T.; Watanabe, M. Fabrication of protic ionic liquid/sulfonated polyimide composite membranes for non-humidified fuel cells. J. Power Sources 2010, 195 (18), 5909-5914.

(44) Schütz, C.; Agthe, M.; Fall, A. B.; Gordeyeva, K.; Guccini, V.; Salajkova, M.; Plivelic, T. S.; Lagerwall, J. P.; Salazar-Alvarez, G.; Bergström, L. Rod packing in chiral nematic cellulose nanocrystal dispersions studied by small-angle $\mathrm{X}$-ray scattering and laser diffraction. Langmuir 2015, 31 (23), 6507-6513.

(45) Liu, Y.; Stoeckel, D.; Gordeyeva, K.; Agthe, M.; Schutz, C.; Fall, A. B.; Bergström, L. Nanoscale assembly of cellulose nanocrystals during drying and redispersion. ACS Macro Lett. 2018, 7 (2), 172177.

(46) Liu, Y.; Agthe, M.; Salajková, M.; Gordeyeva, K.; Guccini, V.; Fall, A.; Salazar-Alvarez, G.; Schütz, C.; Bergström, L. Assembly of cellulose nanocrystals in a levitating drop probed by time-resolved small angle X-ray scattering. Nanoscale 2018, 10 (38), 18113-18118.

(47) Uhlig, M.; Fall, A.; Wellert, S.; Lehmann, M.; Prévost, S.; Wågberg, L.; von Klitzing, R.; Nystrom, G. Two-dimensional aggregation and semidilute ordering in cellulose nanocrystals. Langmuir 2016, 32 (2), 442-450.

(48) Cherhal, F.; Cousin, F.; Capron, I. Influence of charge density and ionic strength on the aggregation process of cellulose nanocrystals in aqueous suspension, as revealed by small-angle neutron scattering. Langmuir 2015, 31 (20), 5596-5602.

(49) Bonini, C.; Heux, L.; Cavaillé, J.-Y.; Lindner, P.; Dewhurst, C.; Terech, P. Rodlike cellulose whiskers coated with surfactant: a smallangle neutron scattering characterization. Langmuir 2002, 18 (8), 3311-3314.

(50) Terech, P.; Chazeau, L.; Cavaille, J. A small-angle scattering study of cellulose whiskers in aqueous suspensions. Macromolecules 1999, 32 (6), 1872-1875.

(51) Penttilä, P. A.; Altgen, M.; Carl, N.; van der Linden, P.; Morfin, I.; Österberg, M.; Schweins, R.; Rautkari, L. Moisture-related changes in the nanostructure of woods studied with $\mathrm{X}$-ray and neutron scattering. Cellulose 2020, 27 (1), 71-87.

(52) Penttilä, P. A.; Rautkari, L.; Österberg, M.; Schweins, R. Smallangle scattering model for efficient characterization of wood nanostructure and moisture behaviour. J. Appl. Crystallogr. 2019, 52 (2), 369-377.

(53) Nechyporchuk, O.; Belgacem, M. N.; Pignon, F. Concentration effect of TEMPO-oxidized nanofibrillated cellulose aqueous suspensions on the flow instabilities and small-angle X-ray scattering structural characterization. Cellulose 2015, 22 (4), 2197-2210.

(54) Wada, M.; Okano, T.; Sugiyama, J. Synchrotron-radiated X-ray and neutron diffraction study of native cellulose. Cellulose 1997, 4 (3), 221-232.

(55) Elazzouzi-Hafraoui, S.; Nishiyama, Y.; Putaux, J.-L.; Heux, L.; Dubreuil, F.; Rochas, C. The shape and size distribution of crystalline nanoparticles prepared by acid hydrolysis of native cellulose. Biomacromolecules 2008, 9 (1), 57-65.
(56) Fernandes, A. N.; Thomas, L. H.; Altaner, C. M.; Callow, P.; Forsyth, V. T.; Apperley, D. C.; Kennedy, C. J.; Jarvis, M. C. Nanostructure of cellulose microfibrils in spruce wood. Proc. Natl. Acad. Sci. U. S. A. 2011, 108 (47), E1195-E1203.

(57) Ibbett, R.; Gaddipati, S.; Hill, S.; Tucker, G. Structural reorganisation of cellulose fibrils in hydrothermally deconstructed lignocellulosic biomass and relationships with enzyme digestibility. Biotechnol. Biofuels 2013, 6 (1), 33.

(58) Chen, M.; Parot, J.; Mukherjee, A.; Couillard, M.; Zou, S.; Hackley, V. A.; Johnston, L. J. Characterization of size and aggregation for cellulose nanocrystal dispersions separated by asymmetrical-flow field-flow fractionation. Cellulose 2020, 27 (4), 2015-2028.

(59) Duchemin, B. Size, shape, orientation and crystallinity of cellulose I $\beta$ by X-ray powder diffraction using a free spreadsheet program. Cellulose 2017, 24 (7), 2727-2741.

(60) Nishiyama, Y.; Johnson, G. P.; French, A. D. Diffraction from nonperiodic models of cellulose crystals. Cellulose 2012, 19 (2), 319336.

(61) Ogawa, Y. Electron microdiffraction reveals the nanoscale twist geometry of cellulose nanocrystals. Nanoscale 2019, 11 (45), 2176721774 . 